\title{
PENGARUH SERVICE DELIVERY TERHADAP KEPUASAN WISATAWAN DALAM MENGGUNAKAN PAKET OUTBOUND DI OBJEK WISATA LINGGARJATI INDAH KABUPATEN KUNINGAN \\ (Survey pada Wisatawan yang Menggunakan Paket Outbound di Objek Wisata Linggarjati Indah Kabupaten Kuningan)
}

\author{
Mega Tresna Asih \\ Elly Malihah \\ Manajemen Pemasaran Pariwisata FPIPS UPI
}

\begin{abstract}
Tourism is one sector of the economy that grew into the industry that provides income benefits for a country in the world. Development and construction of the tourism sector should be used as revenue by developing the existing potential of such natural beauty and culture with the aim of attracting tourists who could be known by foreign tourists. Kuningan district is one of tourist destination that has many attractions of heritage sites in earlier times that have historical value to the District of Kuningan. In addition to review of its history, District of Kuningan is an area that could be developed as a tourism object. Not far from the building of Linggarjati conference, there are available the natural attractions to complement the tourist area of Linggarjati building conference. The place is called Linggarjati Indah. The administrator of Linggarjati Indah of Kuningan District focuses on improving traveler satisfaction through a system of service delivery. Customer satisfaction will be filled if the process of delivering services from providers to consumers in accordance with what is perceived by tourists. This study aims to determine the picture of service delivery, picture of the level of tourist satisfaction and service delivery impact on tourist satisfaction. The object in this study is, that tourists are using outbound package of Linggarjati Indah of Kuningan District. The independent variable in this study is the service delivery $(X)$. And the dependent variable in this study is the satisfaction of tourists $(Y)$. This research uses descriptive and verified method, by the method of explanatory survey. The data analysis technique, the writer uses the technique of multiple regression analysis with SPSS 18.0 program for windows. The results showed that variables of service delivery service facilities, personnel, roles and scripts simultaneously affect the satisfaction of tourists who use the outbound package at Linggarjati Indah of Kuningan District. Whereas only partial personnel and roles that significantly influence tourist satisfaction.
\end{abstract}

Key words: service delivery, tourist satisfaction.

\section{PENDAHULUAN}

\subsection{Latar Belakang}

Pariwisata merupakan salah satu sektor perekonomian yang tumbuh menjadi industri yang memberikan devisa menguntungkan bagi suatu negara di dunia. Menurut Undangundang Nomor 10 Tahun 2009 tentang Kepariwisataan, pariwisata adalah berbagai macam kegiatan wisata dan didukung berbagai fasilitas serta layanan yang disediakan oleh masyarakat, pengusaha, Pemerintah, dan Pemerintah Daerah.

Pariwisata Indonesia tumbuh mengesankan selama tahun 2011. Dari target wisatawan mancanegara 7,1 juta orang, Indonesia mampu mendatangkan sebanyak 7,6 juta orang tahun lalu. Perolehan jumlah wisatawan itu tumbuh 8,5 persen dibanding tahun 2010. Bahkan, kinerja pariwisata
Indonesia mengalahkan dunia yang hanya tumbuh 4,5 persen. Perolehan devisa pariwisata selama 2011 tercatat mencapai US $\$ 8,5$ miliar, atau tumbuh 11,8 persen dibanding tahun sebelumnya US\$7,6 miliar. (http://analisis.vivanews.com, diakses pada 01 Februari 2012).

Pengembangan dan pembangunan sektor pariwisata seharusnya bisa dijadikan pendapatan asli daerah dengan cara mengembangkan potensi yang sudah ada seperti keindahan alam dan kebudayaan dengan tujuan menarik minat wisatawan nusantara yang selanjutnya bisa dikenal oleh wisatawan mancanegara.

Jawa Barat dikenal sebagai provinsi yang memiliki kekayaan budaya dan keragaman sumber daya pariwisata yang tinggi, meliputi wisata alam, wisata budaya dan wisata minat khusus. 
Letak geografis Jawa Barat yang berbatasan langsung dengan ibukota negara Indonesia, DKI Jakarta, menjadikan Jawa Barat memiliki potensi yang strategis bagi pengembangan pariwisata. Selain merupakan pintu gerbang utama Indonesia, DKI Jakarta juga merupakan sumber pasar wisatawan. Disamping itu, keragaman daya tarik wisata yang dimiliki kabupaten/kota di Jawa Barat memberikan alternatif pilihan berwisata yang lebih bervariasi bagi wisatawan. Perkembangan dan pertumbuhan tersebut mempengaruhi tingkat kunjungan wisatawan mancanegara dan wisatawan nusantara di Provinsi Jawa Barat. Berikut ini Tabel 1.1 menunjukan pertumbuhan wisatawan nusantara dan wisatawan mancanegara di Provinsi Jawa Barat tahun 2006-2010.

TABEL 1.1

PERTUMBUHAN WISATAWAN MANCANEGARA DAN WISATAWAN NUSANTARA KE OBJEK WISATA DI PROVINSI JAWA BARAT

TAHUN 2006-2010

\begin{tabular}{|c|c|c|c|c|c|}
\hline \multirow{2}{*}{ Wisatawan } & \multicolumn{5}{|c|}{ Tahun } \\
\cline { 2 - 6 } & $\mathbf{2 0 0 6}$ & $\mathbf{2 0 0 7}$ & $\mathbf{2 0 0 8}$ & $\mathbf{2 0 0 9}$ & $\mathbf{2 0 1 0}$ \\
\hline $\begin{array}{c}\text { Wisatawan } \\
\text { Mancanegara }\end{array}$ & 227.068 orang & 338.959 orang & 330.369 orang & 741.323 orang & $\begin{array}{c}729.987 \\
\text { orang }\end{array}$ \\
\hline $\begin{array}{l}\text { Wisatawan } \\
\text { Nusantara }\end{array}$ & $\begin{array}{c}23.859 .547 \\
\text { orang }\end{array}$ & $\begin{array}{c}23.782 .302 \\
\text { orang }\end{array}$ & $\begin{array}{c}26.287 .031 \\
\text { orang }\end{array}$ & $\begin{array}{c}24.138 .855 \\
\text { orang }\end{array}$ & $\begin{array}{c}25.549 .941 \\
\text { orang }\end{array}$ \\
\hline JUMLAH & $\begin{array}{c}\mathbf{2 4 . 0 8 6 . 6 1 5} \\
\text { orang }\end{array}$ & $\begin{array}{c}\mathbf{2 4 . 1 2 1 . 2 6 1} \\
\text { orang }\end{array}$ & $\begin{array}{c}\mathbf{2 6 . 6 1 7 . 4 0 0} \\
\text { orang }\end{array}$ & $\begin{array}{c}\mathbf{2 4 . 8 8 0 . 1 7 8} \\
\text { orang }\end{array}$ & $\begin{array}{c}\mathbf{2 6 . 2 7 9 . 9 2 8} \\
\text { orang }\end{array}$ \\
\hline
\end{tabular}

Sumber: Disbudpar Provinsi Jawa Barat, 2011

Berdasarkan Tabel 1.1, pertumbuhan wisatawan mancanegara ke objek wisata di Provinsi Jawa Barat mengalami peningkatan dari tahun ke tahun, terutama pada tahun 2009. Pertumbuhan wisatawan mencapai 410.954 wisatawan. Sedangkan wisatawan nusantara meningkat dari tahun 2006 hingga 2008. Pada akhir tahun 2009, tercatat pertumbuhan wisatawan nusantara mengalami penurunan sebanyak 2.148.176 wisatawan. Karena keragaman daya tarik wisata yang dimiliki kabupaten/kota di Provinsi Jawa Barat memberikan alternatif pilihan berwisata yang lebih bervariasi bagi wisatawan, pada akhir tahun 2010, pertumbuhan wisatawan nusantara kembali mengalami kenaikan.

Objek wisata di Jawa Barat memiliki keanekaragaman yang mampu menarik minat wisatawan untuk berkunjung. Daya tarik wisata di Jawa Barat meliputi alam, gunung dan kawah, pantai, sungai dan danau, peninggalan sejarah, seni budaya, wisata konvensi, museum, wisata belanja, menjadikan siapapun yang menikmati kepariwisataan dan kebudayaan Jawa Barat menjadi KATAJI yang mengandung arti terpesona, tertarik karena [Kreatifitas Senimannya andal Tempat Wisatanya Aman di Jelajahi dan (So Pasti) Indah].

Kabupaten Kuningan adalah salah satu daerah tujuan wisata yang memiliki banyak objek wisata berupa situs-situs peninggalan pada jaman dulu yang mempunyai nilai sejarah bagi Kabupaten Kuningan. Sejarah mencantumkan Kuningan sebagai salah satu tempat untuk memperjuangan Indonesia menggapai kemerdekaan, karena di tempat inilah tepatnya 10-13 November tahun 1946 Sutan Syahrir sebagai perwakilan dari Indonesia, Schermerhorn, H.J. Van Mook dari Belanda, dan Lord Killearn merundingkan agar Indonesia bisa merdeka $100 \%$. Kemudian perundingan ini dikenal sebagai Perundingan Linggarjati, karena terletak di Desa Linggarjati, Kecamatan Cilimus, Kabupaten Kuningan, Jawa Barat, kurang lebih $25 \mathrm{~km}$ dari Cirebon.

Selain ditinjau dari sejarahnya, Kabupaten Kuningan merupakan daerah yang bisa dikembangkan sebagai kawasan ekowisata. Bahkan, Kabupaten Kuningan sudah memiliki visi pariwisata yang jelas, yakni "Sektor pariwisata menjadi andalan perekonomian daerah yang berbasiskan sumberdaya alam, budaya yang lestari dan agamis". Untuk mewujudkannya, pembangunan kepariwisataan diutamakan pada penggalian obyek dan pengembangan daya tarik wisata.

Kabupaten Kuningan memiliki sumberdaya alam yang tinggi dan merata. Setiap kecamatan umumnya berpotensi ekowisata. Potensi tersebut berupa air terjun (lembah Cilengkrang), air panas (Sangkanurip), danau/waduk (Waduk Darma, Talaga Remis), kolam renang alami (Cigugur, Cibulan, Linggarjati), dan pemandangan alam 
(Bumi Perkemahan Palutungan, Gunung Ciremai).

Kabupaten Kuningan merupakan salah satu daerah Provinsi Jawa Barat yang memiliki kesuburan dan keindahan alam, kekayaan seni budaya serta berhawa sejuk. Karena terletak di kaki Gunung Ciremai, sebuah gunung tertinggi di Jawa Barat. Objek wisata alam dan sumber air yang ada di beberapa tempat merupakan modal dasar yang tidak dapat dipisahkan dari nilai-nilai tradisi dan budaya yang telah menjadi bagian dari kehidupan masyarakat yang bercorak agraris. Sehingga objek pariwisata yang ada di Kabupaten Kuningan kebanyakan merupakan Objek Wisata Tirta (Air). Berikut Tabel 1.2 mengenai data pengunjung objek wisata di Kabupaten Kuningan tahun 20092011.

TABEL 1.2

DATA PENGUNJUNG OBJEK WISATA KABUPATEN KUNINGAN TAHUN 2009-2011

\begin{tabular}{|c|c|c|c|c|}
\hline \multirow[b]{2}{*}{ NO. } & \multirow[b]{2}{*}{ ODTW } & \multicolumn{3}{|c|}{ JUMLAH PENGUNJUNG WISNUS } \\
\hline & & 2009 & 2010 & $\begin{array}{c}2011 \\
\text { (Jan-Sep) }\end{array}$ \\
\hline 1 & Talaga Remis & 27510 orang & 20302 orang & 34.860 orang \\
\hline 2 & Buper Paniis & 12028 orang & 16122 orang & 43.555 orang \\
\hline 3 & Buper Cibeureum & 1599 orang & 854 orang & - \\
\hline 4 & G. Naskah Linggarjati & 65298 orang & 72068 orang & 51.831 orang \\
\hline 5 & PPGC Cibubur & 10124 orang & 11259 orang & - \\
\hline 6 & Linggarjati Indah & 103.169 orang & $\mathbf{1 1 8 1 7 5}$ orang & 99.751 orang \\
\hline 7 & Sangkanurip Alami & 46916 orang & 55980 orang & 47.209 orang \\
\hline 8 & Curug Sidomba & 10298 orang & 20140 orang & 5.047 orang \\
\hline 9 & Cilengkrang & 13110 orang & 18500 orang & 24.941 orang \\
\hline 10 & Cibulan & 145220 orang & 171013 orang & 137.806 orang \\
\hline 11 & Balong Dalem & 978 orang & 465 orang & 3.387 orang \\
\hline 12 & T. Purbakala Cipari & 8040 orang & 11706 orang & 6.254 orang \\
\hline 13 & Cigugur & 17713 orang & 32435 orang & 79.402 orang \\
\hline 14 & Waduk Darma & 42750 orang & 55848 orang & 15.528 orang \\
\hline 15 & Darmaloka & 10180 orang & 7665 orang & - \\
\hline 16 & Buper Palutungan & 16814 orang & 20998 orang & 51.690 orang \\
\hline 17 & K. R Sanggariang & 35831 orang & 32287 orang & 20.108 orang \\
\hline 18 & K.R Tirta Agung & 75986 orang & 56810 orang & 24.794 orang \\
\hline 19 & K.R ABN & 17709 orang & 12668 orang & - \\
\hline & JUMLAH & 659503 orang & 735295 orang & 646.163 orang \\
\hline
\end{tabular}

Sumber: Dinas Pariwisata dan Kebudayaan Kabupaten Kuningan, 2012

Berdasarkan Tabel 1.2, objek wisata yang paling banyak dikunjungi di Kabupaten Kuningan dari tahun 2009 hingga tahun 2011 adalah Cibulan. Tahun 2010, kunjungan wisatawan di Cibulan naik hingga 25.793 orang. Sedangkan Linggarjati Indah menempati posisi kedua setelah Cibulan di tahun 2009 dan 2010. Kunjungan di Linggarjati Indah naik hingga 16.776 wisatawan.

Tidak jauh dari Gedung Perundingan Linggarjati, tersedia objek wisata alam sebagai pelengkap wisata Gedung Perundingan Linggarjati. Tempat tersebut terdiri dari pohon-pohon yang rindang dan dilengkapi dengan fasilitas lain seperti kolam renang standar nasional dan dilengkapi 2 buah luncuran sepanjang $25 \mathrm{~m}$, sepeda air, aneka mainan anak-anak, kolam pancing, outbound, camping ground, sport center, restoran, karaoke, billyard, pondok-pondok penginapan bagi pengunjung yang ingin menginap dan kios-kios cenderamata.

Dari tahun 2009 hingga 2010, Objek Wisata Linggarjati Indah bertahan dalam urutan kedua objek wisata yang paling banyak dikunjungi di Kabupaten Kuningan. Tingkat kunjungan di Linggarjati pun meningkat dari tahun ke tahun. Jumlah wisatawan yang berkunjung ke Objek Wisata Linggarjati Indah kebanyakan berasal dari wilayah III Cirebon, yaitu Cirebon, Indramayu, Majalengka, dan Kuningan. Berikut Tabel 1.3 mengenai data kunjungan wisatawan nusantara di Objek Wisata Linggarjati Indah Kabupaten Kuningan tahun 2005-2011. 
TABEL 1.3

DATA PENGUNJUNG WISATAWAN NUSANTARA OBJEK WISATA LINGGARJATI INDAH KABUPATEN KUNINGAN TAHUN 2005-2011

\begin{tabular}{|c|c|}
\hline TAHUN & JUMLAH PENGUNJUNG \\
\hline 2005 & 69.347 orang \\
\hline 2006 & 88.105 orang \\
\hline 2007 & 93.693 orang \\
\hline 2008 & 93.447 orang \\
\hline 2009 & 103.169 orang \\
\hline 2010 & 118.175 orang \\
\hline 2011 & 121.828 orang \\
\hline \multicolumn{2}{|c|}{ Sumber: Objek Wisata Linggarjati Indah, Kabupaten Kuningan, 2012 }
\end{tabular}

Dari Tabel 1.3, terlihat jelas bahwa Objek Wisata Linggarjati Indah mengalami kenaikan jumlah pengunjung dari tahun ke tahun. Tahun 2008, kunjungan di Linggarjati Indah mengalami sedikit penurunan, yaitu sebanyak 246 wisatawan. Namun tahun berikutnya kunjungan di Linggarjati Indah meningkat hingga tahun 2011. Kenaikan jumlah kunjungan tiap tahun dikarenakan Objek Wisata Linggarjati Indah menerapkan one stop service yaitu pengunjung dapat melakukan berbagai kegiatanatau aktifitas wisata di satu tempat yaitu aktifitas rekreasi, wisata alam, outbound, serta akomodasi.

Dari tingkat kunjungan Objek Wisata Linggarjati Indah yang terus meningkat, salah satu atraksi wisata yang menarik bagi wisatawan yang berkunjung ke Objek Wisata Linggarjati Indah adalah paket outbound. Berikut Gambar 1.1 mengenai persentase kunjungan wisatawan ke Objek Wisata Linggarjati Indah berdasarkan atraksi wisata yang tersedia.



Sumber : Objek Wisata Linggarjati Indah Kabupaten Kuningan, 2012

GAMBAR 1.1

\section{PERSENTASE KUNJUNGAN WISATAWAN BERDASARKAN ATRAKSI WISATA DI OBJEK WISATA LINGGARJATI INDAH}

Berdasarkan Gambar 1.1 diatas, sebanyak $43 \%$ dari total keseluruhan wisatawan yang berkunjung ke Objek Wisata Linggarjati Indah menggunakan paket outbound. Sebanyak 33\% wisatawan menggunakan aktifitas rekreasi seperti kolam renang, sepeda air, aneka permainan anakanak serta kolam pancing. Sisanya, yaitu wisata alam dan akomodasi masing-masing $12 \%$. Berdasarkan jumlah paket outbound yang merupakan atraksi wisata yang dominan, maka survey dilakukan hanya dalam paket outbound.

Paket outbound yang terdapat di Objek Wisata Linggarjati Indah terdiri dari berbagai aneka permainan, seperti jembatan elvis, paintball, rakit, flying fox dan spider web. Pihak Objek Wisata Linggarjati Indah memberikan beberapa paket untuk wisatawan yang berkunjung. Berikut Tabel 1.4 merupakan paket outbound yang ditawarkan oleh Objek Wisata Linggarjati Indah: 
TABEL 1.4

PAKET OUTBOUND DI OBJEK WISATA LINGGARJATI INDAH

\begin{tabular}{|c|l|l|}
\hline NO & \multicolumn{1}{|c|}{ PILIHAN PAKET } & \multicolumn{1}{c|}{ DESKRIPSI } \\
\hline 1. & $\begin{array}{l}\text { Paket 1 (half day) } \\
\text { Pukul 09.00-13.00 }\end{array}$ & $\begin{array}{l}\text { Rp. 75.000,- (Net) per pax, min 25 orang, } \\
\text { sudah termasuk makan 1x, snack 1x, } \\
\text { instruktur, dan pemakaian fasilitas } \text { outbound. }\end{array}$ \\
\hline 2. & $\begin{array}{l}\text { Paket 2 (full day) } \\
\text { Pukul 09.00-15.00 }\end{array}$ & $\begin{array}{l}\text { Rp. 125.000,- (Net) per pax, min 25 orang, } \\
\text { sudah termasuk makan 1x, snack 2x, } \\
\text { instruktur, dan pemakaian fasilitas } \text { outbound. }\end{array}$ \\
\hline
\end{tabular}

Sumber: Linggarjati Indah, Kabupaten Kuningan, 2012

Kedua paket tersebut selalu menarik minat wisatawan untuk menggunakan paket outbound di Objek Wisata Linggarjati Indah karena harga yang ditawarkan sangat terjangkau.
Dalam Tabel 1.5 berikut dapat dilihat persentase jumlah wisatawan yang menggunakan kedua paket outbound di Objek Wisata Linggarjati Indah.

TABEL 1.5

PERSENTASE WISATAWAN YANG MENGGUNAKAN PAKET OUTBOUND DI OBJEK WISATA LINGGARJATI INDAH

\begin{tabular}{|c|c|c|c|}
\hline NO & TAHUN & $\begin{array}{c}\text { PERSENTASE } \\
\text { PENGUNJUNG } \\
(\boldsymbol{F U L L ~ D A Y )}\end{array}$ & $\begin{array}{c}\text { PERSENTASE } \\
\text { PENGUNJUNG } \\
(\text { HALF DAY })\end{array}$ \\
\hline 1. & 2008 & $10 \%$ & $9 \%$ \\
\hline 2. & 2009 & $15 \%$ & $17 \%$ \\
\hline 3. & 2010 & $19 \%$ & $20 \%$ \\
\hline 4. & 2011 & $20 \%$ & $23 \%$ \\
\hline
\end{tabular}

Sumber: Linggarjati Indah, Kabupaten Kuningan, 2012

Dalam Tabel 1.5 di atas, terlihat jelas bahwa setiap tahunnya, wisatawan yang menggunakan paket outbound di Objek Wisata Linggarjati Indah mengalami peningkatan. Tingkat penggunaan paket outbound yang meningkat ini, tidak bisa dijadikan indikator kepuasan wisatawan yang menggunakan paket outbound di Objek Wisata Linggarjati Indah Kabupaten Kuningan.

Mempunyai pelanggan atau wisatawan yang puas merupakan hal yang penting bagi industri jasa. Kotler and Amstrong (2012:37) menyatakan bahwa customer satisfaction is the extent to which a product's perceived performance matches a buyer's expectations. Dalam mencapai kepuasan wisatawan harus dimulai dengan pandangan secara menyeluruh mengenai wisatawan. Yang perlu diingat disini bahwa wisatawan adalah aset strategis yaitu sesuatu yang berjumlah sedikit dan harus diperlakukan dengan hati-hati.
Pencapaian kepuasan dapat merupakan proses yang sederhana, maupun kompleks dan rumit. Untuk dapat mengetahui tingkat kepuasan pengunjung atau pelanggan secara lebih baik, maka perlu dipahami pula sebabsebab kepuasan. Pengunjung tidak hanya kecewa terhadap jasa yang diterima karena pengunjung pun ikut terlibat dalam proses penciptaan jasa.

Ketidakpuasan wisatawan meningkat pada kategori pelayanan yang diberikan, hal ini diidentifikasi dari adanya keluhan wisatawan yang diperoleh dari guest comment yang terbagi dalam tiga kategori yaitu fasilitas, harga dan pelayanan. Berikut ini Gambar 1.2 mengenai persentase kepuasan wisatawan dalam menggunakan paket outbound di Objek Wisata Linggarjati Indah Kabupaten Kuningan hasil pengolahan pihak marketing Objek Wisata Linggarjati Indah Kabupaten Kuningan. 


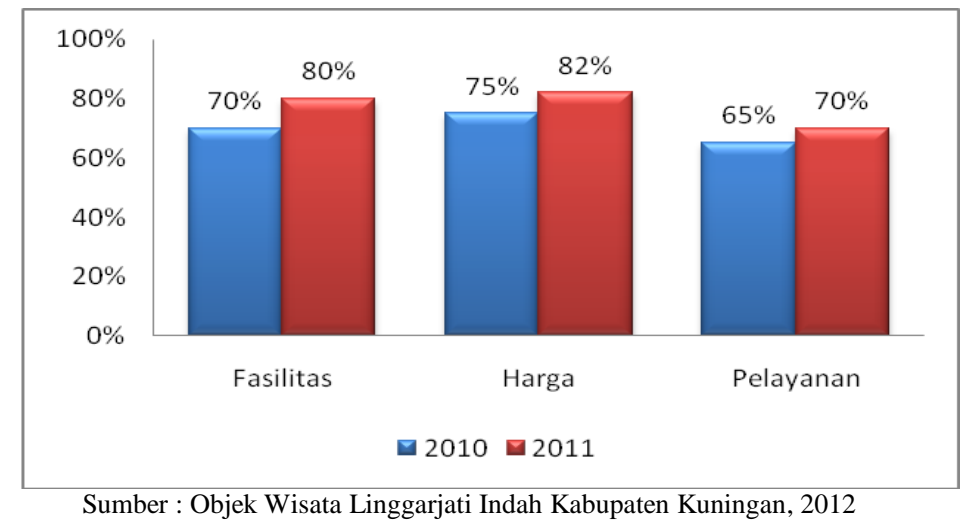

\section{GAMBAR 1.2 \\ PERSENTASE KEPUASAN WISATAWAN DALAM MENGGUNAKAN PAKET OUTBOUND DI OBJEK WISATA LINGGARJATI INDAH KABUPATEN KUNINGAN}

Berdasarkan Gambar 1.2 di atas pihak marketing Objek Wisata Linggarjati Indah Kabupaten Kuningan menyatakan bahwa secara keseluruhan tingkat kepuasan wisatawan sudah cukup baik. Hal ini karena adanya perbaikan-perbaikan setiap tahunnya serta lengkapnya fasilitas-fasilitas atau alatalat outbound. Berdasarkan hasil wawancara dengan beberapa wisatawan yang menggunakan paket outbound, kepuasan wisatawan meningkat pada kategori harga. Harga paket yang ditawarkan pihak Objek Wisata Linggarjati Indah sangat terjangkau dengan fasilitas yang lengkap sehingga wisatawan merasa puas.

Salah satu indikator yang perlu diperhatikan dalam hal ini adalah pelayanan, pelayanan yang terdiri dari berbagai aspek baik secara langsung ataupun tidak langsung dapat memberikan suatu dampak yang besar terhadap kepuasan konsumen.

Seperti yang dikemukakan oleh pihak marketing Objek Wisata Linggarjati Indah, bahwa wisatawan yang memilih dan menggunakan paket outbound di Objek Wisata Linggarjati Indah dikarenakan harga yang ditawarkan sangat terjangkau dengan fasilitas yang lengkap jika dibandingkan dengan fasilitas outbound di objek wisata lain. Akan tetapi berdasarkan kinerja yang dirasakan belum cukup untuk memberikan kepuasan terhadap wisatawan yang berkunjung karena dalam hal ini kinerja yang dirasakan memberikan dampak yang sangat besar terhadap wisatawan. Pelayanan dalam hal ini adalah proses penyampaian jasa yang dirasakan kurang begitu baik sehingga wisatawan merasakan ketidakpuasan terhadap apa yang mereka rasakan.
Pada dasarnya, kepuasan merupakan tingkat perasaan seseorang setelah membandingkan kinerja atau hasil yang ia rasakan dibandingkan dengan harapannya. Apabila persepsi terhadap kinerja tidak bisa memenuhi harapan, maka yang terjadi adalah ketidakpuasan. Sebaliknya jika persepsi terhadap kinerja bisa memenuhi harapan konsumen akan merasa sangat puas. Harapan wisatawan dapat dibentuk oleh pengalaman pembelian terdahulu, komentar teman dan kenalannya, serta janji dan informasi pemasar dan sainggannya.

Strategi yang dilakukan pihak Objek Wisata Linggarjati Indah Kabupaten Kuningan yaitu berfokus pada upaya untuk meningkatkan kepuasan wisatawan melalui sistem penyampaian jasa. Service delivery yang dilakukan oleh perusahaan pada dasarnya berfokus pada upaya untuk memberikan kepuasan kepada para pelanggannya. Kepuasan konsumen akan terpenuhi apabila proses penyampaian jasa dari penyedia jasa kepada konsumen sesuai dengan apa yang dipersepsikan wisatawan. Jika sistem penyampaian jasa kurang sesuai dengan keinginan wisatawan, maka perusahaan tersebut akan ditinggalkan pelanggannya dan memilih perusahaan lain.

Peranan instruktur outbound sangat penting sebagai ujung tombak kegiatan outbound khususnya di Objek Wisata Linggarjati Indah yang mempunyai tugas dan tanggung jawab sendiri dalam menyampaikan jasa kepada wisatawan. Pelayanan yang diberikan oleh instruktur outbound haruslah mencerminkan pendekatan seutuhnya dari seorang karyawan kepada wisatawan. Hal ini dilakukan dengan sikap menolong, bersahabat, memberi semangat dan 
profesional yang akan memberikan kepuasan kepada wisatawan.

Service delivery berkaitan dengan dimana, kapan, dan bagaimana jasa disampaikan kepada pelanggan. Strategi pelayanan yang diterapkan meliputi empat komponen, yaitu mencakup service facilities, personnel, role dan scripts yaitu mencakup kualitas dari orang yang memberikan pelayanan serta sentuhan fisik yang dapat membantu memproduksi jasa ataupun mengingatkan pelanggan akan keberadaannya. Kualitas dari penyampaian jasa berarti orang dan cara mereka menggunakan pengetahuannya menyampaikan jasa itu sendiri. Oleh karena itu kualitas jasa sangat tergantung pada kualitas dari orang yang memberikan jasa tersebut. Bukti fisik itu berupa corporate image yang terbentuk melalui warna, desain, logo, dekorasi, seragam pegawai, atau bahkan standarisasi pelayanan yang dapat menyediakan suatu image yang konkret akan suatu perusahaan penyedia jasa bagi konsumen.

Berdasarkan latar belakang penelitian tersebut, penulis tertarik mengadakan penelitian dengan judul PENGARUH SERVICE DELIVERY TERHADAP KEPUASAN WISATAWAN DALAM MENGGUNAKAN PAKET OUTBOUND DI OBJEK WISATA LINGGARJATI INDAH KABUPATEN KUNINGAN.

\subsection{Rumusan Masalah}

Berdasarkan uraian pada latar belakang, dapat diidentifikasikan beberapa permasalahan sebagai berikut:

1. Bagaimana gambaran service delivery di Objek Wisata Linggarjati Indah Kabupaten Kuningan.

2. Bagaimanakah kepuasan wisatawan yang menggunakan paket outbound di Objek Wisata Linggarjati Indah Kabupaten Kuningan.

3. Bagaimana pengaruh service delivery terhadap kepuasan wisatawan yang menggunakan paket outbound di Objek Jasa telah tumbuh secara dramatis dalam beberapa tahun terakhir. Sektor jasa sangat berperanan signifikan dalam perekonomian dunia. Selain itu, jasa juga merupakan salah satu sumber lapangan kerja. Jasa merupakan aktivitas ekonomi yang hasilnya bukan berbentuk produk fisik atau konstruksi, yang umumnya dihasilkan dan dikonsumsi secara bersamaan serta memberikan nilai tambah wisatawan.
Wisata Linggarjati Indah Kabupaten Kuningan.

\subsection{Tujuan Penelitian}

Berdasarkan rumusan masalah di atas, maka tujuan penelitian ini adalah:

1. Untuk memperoleh gambaran mengenai service delivery di Objek Wisata Linggarjati Indah Kabupaten Kuningan.

2. Untuk memperoleh gambaran mengenai kepuasan wisatawan yang menggunakan paket outbound di Objek Wisata Linggarjati Indah Kabupaten Kuningan .

3. Untuk memperoleh temuan mengenai pengaruh service delivery terhadap kepuasan wisatawan yang menggunakan paket outbound di Objek Wisata Linggarjati Indah Kabupaten Kuningan.

\subsection{Kegunaan Penelitian}

Penelitian ini diharapkan dapat memberikan sumbangan baik secara teoritis maupun praktis sebagai berikut:

1. Penelitian ini diharapkan dapat memberikan sumbangan aspek teoritis (keilmuan) yaitu sebagai kajian pengembangan ilmu pemasaran dalam hal ini service delivery. Kegunaan lainnya yaitu hasil penelitian ini diharapkan dapat melengkapi kepustakaan khususnya mengenai materi yang berkaitan dengan salah satu industri yang bergerak dalam bidang jasa yaitu destinasi.

2. Penelitian ini diharapkan juga dapat memberikan sumbangan dalam aspek praktis (guna laksana) yaitu untuk memberikan sumbangan pemikiran bagi Objek Wisata Linggarjati Indah Kabupaten Kuningan serta Dinas Pariwisata dan Kebudayaan Kabupaten Kuningan dalam memberikan persepsi mengenai service delivery terhadap kepuasan wisatawan.

\section{KERANGKA PEMIKIRAN}

\subsection{Kerangka Pemikiran}

Walaupun pada umumnya jasa adalah "produk", namun jasa memiliki karakteristik spesial dan kebutuhan pemasaran. Perbedaan terbesar terletak pada esensi bahwa jasa tidak berwujud dan menciptakan interaksi langsung dengan konsumen. Karakteristik jasa yang tak berwujud, dapat musnah, tak terpisahkan, serta bergantung pada siapa yang menyediakan jasa itu dan kapan, dimana, dan bagaimana jasa itu disediakan, memiliki 
faktor yang sangat krusial dalam hal penyampaian jasa.

Perilaku konsumen merupakan proses dan aktivitas ketika seseorang berhubungan dengan pencarian, pemiihan, pembelian, penggunaan, serta pengevaluasian produk dan jasa demi memenuhi kebutuhan dan keinginan. Selain itu perilaku konsumen mengarah pada pemahaman penyedia jasa mengenai keputusan pembelian dan penggunaan jasa serta apa yang menentukan kepuasan pelanggan setelah mengkonsumsi jasa tersebut/service consumption.

Service consumption dibagi menjadi 3 bagian, yaitu prepurchase, service encounter, dan postencounter. Prepurchase stage dimulai dengan need arousal, yaitu kesadaran pelanggan akan kebutuhan melalui pencarian informasi dan evaluasi dari alternatif untuk menentukan apakah akan membeli atau tidak. Setelah membuat keputusan, pelanggan berpindah ke service experience, yaitu mencakup interaksi/kontak dengan penyedia jasa atau service encounter stage. Dalam postencounter stage dalam service consumption, pelanggan mengevaluasi kinerja layanan yang mereka dapatkan.

Selanjutnya, jasa bisa dikatakan sebagai suatu sistem, yaitu produk jasa yang ditawarkan kepada konsumen yang meliputi service operation system, service delivery system, dan service marketing system.

Penyerahan jasa berhubungan dengan dimana, bilamana, dan bagaimana jasa tersebut diserahkan kepada pelanggan. Sistem ini tidak hanya meliputi unsur-unsur sistem operasi pelayanan jasa yang nyata yaitu dukungan fisik dan personal, tetapi juga termasuk hal-hal yang disajikan kepada pelanggan yang lain. Secara tradisional interaksi antara penyedia jasa dengan pelanggannya termasuk hal yang sangat erat, tetapi karena alasan efisiensi operasional maupun kenyamanan konsumen masyarakat yang mencari jasa tidak memerlukan kehadirannya secara fisik mendapati kenyataan bahwa hubungan langsung mereka dengan perusahaan pelayanan jasa itu ternyata berkurang.

Service delivery system termasuk subsistem yang terlihat dari service operations, peralatan, dan tenaga serta pelanggan lainnya. Dengan menggunakan analogi teater, front office terlihat seperti sebuah teater hidup dimana panggung merupakan service experience bagi pelanggan.
Untuk mendapatkan hasil yang baik dalam memberikan kepuasan wisatawan, perusahaan harus mempunyai suatu service delivery system atau sistem penyajian jasa yang baik.

Selama service delivery, banyak customer mulai mengevaluasi kualitas jasa yang mereka terima dan memutuskan apakah sesuai dengan harapan mereka.

Service delivery diibaratkan seperti theater as metaphor, karena service delivery terdiri dari rangkaian peristiwa/event dalam service experience. Metafora ini adalah pendekatan yang sangat berguna bagi penyedia jasa yang memiliki kontak tinggi dengan konsumen (high-contact service) dan melayani banyak orang secara bersamaan. Lovelock and Wirtz (2011:71) membagi theater as metaphor for service delivery menjadi 4 dimensi yaitu :

1. Service facilities, imagine service facilities as containing the stage on which the drama unfolds. Sometimes the setting changes from one act to another.

2. Personnel, the front-stage personnel are like the members of a cast, playing roles as actors in a drama, and supported by a back-stage production team.

Selain service facilities dan personnel, theater metaphor juga termasuk peran (roles) seriap pemain drama dan naskah (scripts) yang harus pemain ikuti.

3. Roles, a set of behavior patterns learned through experience and communication, to be performed by an individual in a certain social interaction in order to attain maximum effectiveness in gol acomplishment.

4. Scripts, specifies the sequences of behavior for customers and employees are expected to learn and follow during service delivery.

Berdasarkan penjelasan teori di atas, dapat diketahui bahwa service delivery dilakukan untuk memperbaiki sistem penyampaian jasa yang bersumber dari bauran pemasaran jasa yang kurang terkontrol, sehingga dapat meningkatkan kepuasan pelanggan. Keterkaitan antara dua konsep di atas merupakan kerangka berpikir yang dijadikan landasan dalam penelitian sebagaimana terlihat dalam gambar di bawah ini : 


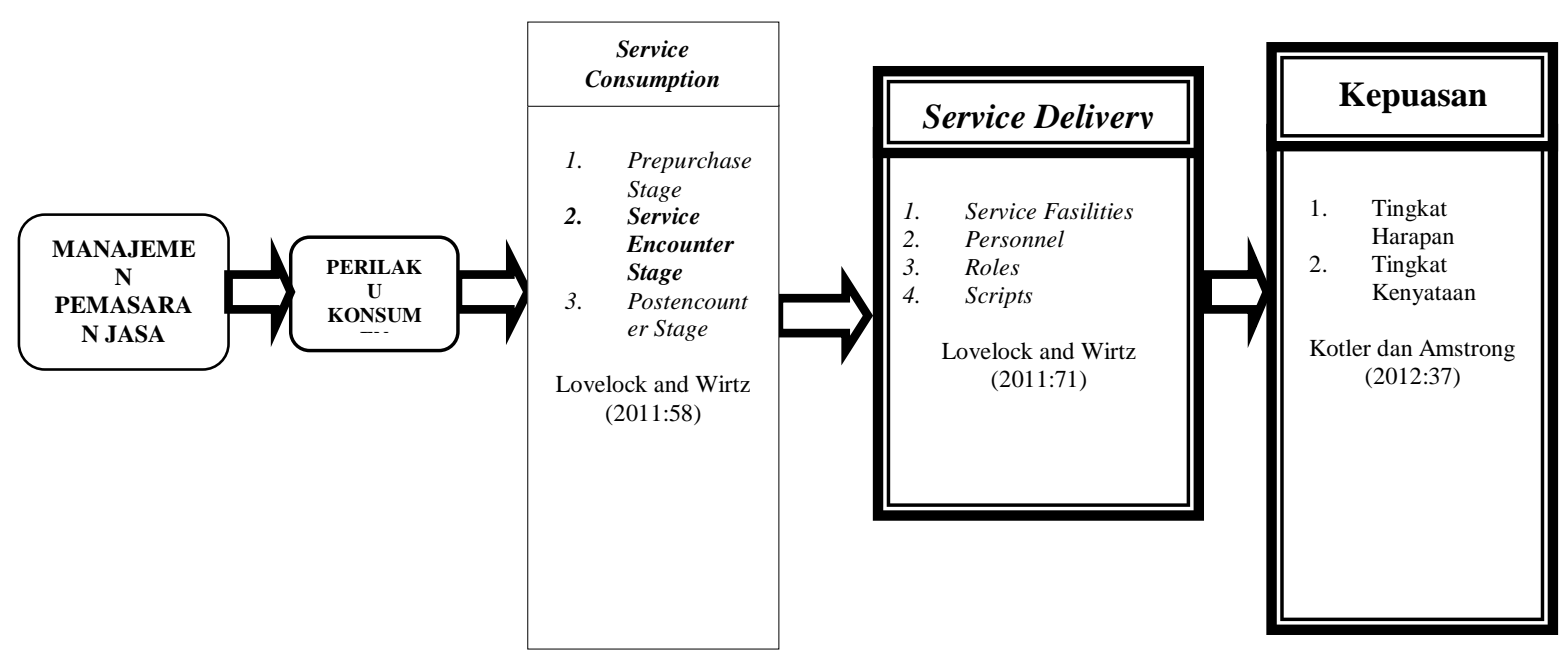

GAMBAR 2.1

KERANGKA PEMIKIRAN PENGARUH SERVICE DELIVERY TERHADAP KEPUASAN WISATA WAN DALAM MENGGUNAKAN PAKET OUTBOUND DI OBJEK WISATA LINGGARJATI INDAH KABUPATEN KUNINGAN

\subsection{Hipotesis Penelitian}

Menurut Sugiyono (2010:93) hipotesis merupakan jawaban sementara terhadap rumusan masalah penelitian, dimana rumusan masalah penelitian telah dinyatakan dalam bentuk kalimat pertanyaan, dikatakan sementara karena jawaban yang diberikan baru didasarkan pada teori yang relevan, belum didasarkan pada fakta-fakta empiris yang diperoleh melalui pengumpulan data, sehingga hipotesis dapat dinyatakan sebagai

Peneliti dalam menyusun hipotesis didukung oleh beberapa premis yang menyatakan pengaruh service delivery terhadap kepuasan pelanggan yaitu sebagai berikut:

1. Lovelock, 2005:59

Dengan sistem penyajian jasa yang baik maka konsumen akan merasa puas dengan pelayanan yang diberikan oleh perusahaan.

2. Lovelock and Wirtz, 2011: 77

Managing customers behavior in the three stages of service consumption effectively is central to creating satisfied customers who will be willing to enter into long-term relationship with the service provider.

Berdasarkan premis-premis di atas, maka hipotesis dalam penelitian ini adalah: "Terdapat pengaruh yang signifikan antara service delivery yang terdiri dari service facilities, personnel, roles dan scripts terhadap kepuasan wisatawan dalam menggunakan paket outbound di Objek jawaban teoritis terhadap rumusan masalah penelitian, belum jawaban yang empirik.

Hipotesis menyatakan hubungan apa yang dicari atau yang ingin dipelajari. Hipotesis adalah pernyataan yang diterima secara sementara sebagai suatu kebenaran sebagaimana adanya pada saat fenomena dikenal dan merupakan dasar kerja serta panduan dalam verifikasi. Hipotesis adalah keterangan sementara dari hubungan fenomena yang kompleks.

Wisata Linggarjati Indah Kuningan" (didukung oleh premis 1 dan 2).

\section{METODE PENELITIAN}

\subsection{Objek Penelitian}

Penelitian ini menganalisis tentang strategi pemasaran jasa Objek Wisata Linggarjati Indah Kabupaten Kuningan melalui program service delivery. Objek penelitian yang menjadi variabel bebas atau independent variable yaitu, service delivery (X) yang memiliki empat sub variabel, service facilities $\left(\mathrm{X}_{1}\right)$, personnel $\left(\mathrm{X}_{2}\right)$, roles $\left(\mathrm{X}_{3}\right)$ dan scripts $\left(\mathrm{X}_{4}\right)$. Masalah penelitian yang merupakan penelitian variabel terikat atau dependent variable adalah kepuasan (Y) yang memiliki indikator berdasarkan tingkat harapan (expectations) dan tingkat kenyataan (perceptions).

Unit analisis dari penelitian ini adalah wisatawan yang menggunakan paket outbound di Objek Wisata Linggarjati Indah Kabupaten Kuningan. Berdasarkan objek penelitian di atas, maka akan dianalisis 
mengenai pengaruh service delivery dalam meningkatkan kepuasan wisatawan pada Objek Wisata Linggarjati Indah Kabupaten Kuningan.

\subsection{Metode Penelitian}

Metode penelitian pada dasarnya merupakan cara ilmiah untuk mendapatkan data dengan tujuan dan kegunaan memecahkan suatu masalah. Menurut Sugiyono (2011:1) yang dimaksud dengan "metode penelitian adalah cara ilmiah untuk mendapatkan dan dengan tujuan dan kegunaan tertentu". Berdasarkan tujuan penelitian dan variabel-variabel yang diteliti, maka jenis penelitian ini adalah penelitian deskriptif dan verifikatif, yaitu menguji kebenaran suatu hipotesis yang telah diuraikan pada Bab II, melalui pengumpulan data di lapangan (wisatawan yang menggunakan paket outbound di Objek Wisata Linggarjati Indah Kabupaten Kuningan). Agar tercapai tujuan dari penelitian ini maka diperlukan suatu metode dan teknik penelitian yang sesuai.

Penelitian deskriptif dilakukan untuk mengetahui nilai variabel mandiri, baik satu variabel atau lebih (independen) tanpa membuat perbandingan, atau menghubungkan dengan variabel lain. Penelitian deskriptif di dalam penelitian ini bertujuan untuk memperoleh deskripsi atau gambaran mengenai strategi service delivery (service facilities, personnel, roles, dan scripts) dan kepuasan wisatawan dalam menggunakan paket outbound di Objek Wisata Linggarjati Indah Kabupaten Kuningan.

Sedangkan jenis penelitian verifikatif menguji kebenaran suatu hipotesis yang dilakukan melalui pengumpulan data di lapangan. Penelitian ini akan diuji mengenai kebenaran hipotesis melalui pengumpulan data di lapangan, dalam hal ini dilakukan melalui survey terhadap wisatawan yang menggunakan paket outbound di Objek Wisata Linggarjati Indah Kuningan untuk mengetahui pengaruh service delivery (service facilities, personnel, roles, dan scripts) terhadap kepuasan wisatawan.

\subsubsection{Jenis dan Metode yang Digunakan}

Dalam suatu penelitian diperlukan suatu metode untuk mempermudah penulis dalam membuat suatu kesimpulan. Berdasarkan jenis penelitian deskriptif dan verifikatif tersebut yang dilaksanakan melalui pengumpulan data di lapangan, maka metode penelitian yang digunakan dalam penelitian ini adalah explanatory survey. Menurut Sugiyono (2010:11) mengemukakan bahwa:

Penelitian survey adalah penelitian yang digunakan untuk mendapatkan data dari tempat tertentu yang alamiah (bukan buatan), tetapi peneliti melakukan perlakuan dalam pengumpulan data, misalnya dengan mengedarkan kuesioner, test, wawancara terstruktur dan sebagainya (perlakuan tidak seperti dalam eksperimen).

Penelitian dengan menggunakan metode ini yaitu informasi dari sebagian populasi dikumpulkan langsung di tempat kejadian secara empiris dengan tujuan untuk mengetahui pendapat dari sebagian populasi terhadap objek yang sedang diteliti. Penelitian ini dilakukan dalam jangka waktu kurang dari satu tahun, yaitu mulai dari Februari 2012 hingga Agustus 2012, oleh karena itu metode pengembangan yang digunakan adalah cross sectional. Menurut Husein Umar (2009:45) "Metode cross sectional adalah metode penelitian dengan cara memperbaiki objek dalam kurun waktu tertentu/tidak berkesinambungan dalam jangka waktu panjang.

\subsubsection{Operasionalisasi Variabel}

Penelitian ini meliputi dua variabel inti, yaitu variabel bebas dan variabel terikat. Variabel yang akan dikaji dalam penelitian ini meliputi service delivery (X). Sub variabel service delivery terdiri dari service facilities $\left(\mathrm{X}_{1}\right)$, personnel $\left(\mathrm{X}_{2}\right)$, roles $\left(\mathrm{X}_{3}\right)$ dan scripts $\left(\mathrm{X}_{4}\right)$. Variabel lainnya yang diteliti adalah kepuasan wisatawan (Y) yang terdiri dari tingkat harapan (expectations) dan tingkat kenyataan (perceived).

Pengaruh variabel-variabel tersebut dapat dianalisis melalui pengukuran veriabelvariabel penelitian yang dijelaskan dalam tabel operasionalisasi variabel. Pengoperasian variabel dari kedua variabel yang dijadikan objek pada penelitian ini menggunakan skala ordinal, yaitu data yang berjenjang atau berbentuk peringkat, tidak hanya menyatakan peringkat kategori tapi menyatakan peringkat kategori tersebut. Secara lebih rinci operasionalisasi variabel dalam penelitian ini digambarkan dalam Tabel 3.1 sebagai berikut: 
TABEL 3.1

OPERASIONALISASI VARIABEL PENELITIAN

\begin{tabular}{|c|c|c|c|c|c|}
\hline $\begin{array}{l}\text { Variabel/Sub } \\
\text { Variabel }\end{array}$ & Konsep & Indikator & Ukuran & Skala & $\begin{array}{l}\text { No. Item } \\
\text { Pertanyaan }\end{array}$ \\
\hline $\begin{array}{l}\text { Service Delivery } \\
(\mathbf{X})\end{array}$ & \multicolumn{5}{|c|}{$\begin{array}{l}\text { Service delivery is where the final "assembly" takes place and the product is delivered to the } \\
\text { customer. (Lovelock and Wright, 2011:70). }\end{array}$} \\
\hline $\begin{array}{c}\text { Service } \\
\text { facilities }\left(\mathbf{X}_{1}\right)\end{array}$ & $\begin{array}{l}\text { Imagine service } \\
\text { facilities as } \\
\text { containing the stage } \\
\text { on which the drama } \\
\text { unfolds. Sometimes } \\
\text { the setting changes } \\
\text { from one act to } \\
\text { another. } \\
\text { Lovelock and } \\
\text { Wirtz }(\mathbf{2 0 1 1 : 7 1 )}\end{array}$ & $\begin{array}{l}\text { Keindahan } \\
\text { landscape di area } \\
\text { outbound. }\end{array}$ & $\begin{array}{l}\text { Tingkat keindahan } \\
\text { landscape di area } \\
\text { outbound. }\end{array}$ & Ordinal & C.1.1 \\
\hline & & $\begin{array}{l}\text { Kenyamanan lokasi } \\
\text { pelaksanaan } \\
\text { outbound. }\end{array}$ & $\begin{array}{l}\text { Tingkat kenyamanan } \\
\text { lokasi pelaksanaan } \\
\text { outbound. }\end{array}$ & Ordinal & C.1.2 \\
\hline & & $\begin{array}{l}\text { Kebersihan area } \\
\text { outbound. }\end{array}$ & $\begin{array}{l}\text { Tingkat kebersihan } \\
\text { area outbound. }\end{array}$ & Ordinal & C.1.3 \\
\hline & & $\begin{array}{l}\text { Kelengkapan } \\
\text { fasilitas alat-alat } \\
\text { outbound. }\end{array}$ & $\begin{array}{l}\text { Tingkat kelengkapan } \\
\text { fasilitas alat-alat } \\
\text { outbound. }\end{array}$ & Ordinal & C.1.4 \\
\hline & & $\begin{array}{l}\text { Keamanan fasilitas } \\
\text { alat-alat outbound. }\end{array}$ & $\begin{array}{l}\text { Tingkat keamanan } \\
\text { fasilitas alat-alat } \\
\text { outbound. }\end{array}$ & Ordinal & C.1.5 \\
\hline & & $\begin{array}{l}\text { Kelayakan kondisi } \\
\text { fasilitas alat-alat } \\
\text { outbound. }\end{array}$ & $\begin{array}{l}\text { Tingkat kelayakan } \\
\text { kondisi fasilitas alat- } \\
\text { alat outbound. }\end{array}$ & Ordinal & C.1.6 \\
\hline & & $\begin{array}{l}\text { Kenyamanan } \\
\text { fasilitas yang } \\
\text { tersedia di area } \\
\text { outbound. }\end{array}$ & $\begin{array}{l}\text { Tingkat kenyamanan } \\
\text { fasilitas yang } \\
\text { tersedia di area } \\
\text { outbound. }\end{array}$ & Ordinal & C.1.7 \\
\hline
\end{tabular}


Lanjutan Tabel 3.1

\begin{tabular}{|c|c|c|c|c|c|}
\hline $\begin{array}{c}\text { Variabel/Sub } \\
\text { Variabel }\end{array}$ & Konsep & Indikator & Ukuran & Skala & $\begin{array}{l}\text { No. Item } \\
\text { Pertanyaan }\end{array}$ \\
\hline \multirow{5}{*}{ Personnel $\left(\mathbf{X}_{2}\right)$} & \multirow{5}{*}{$\begin{array}{l}\text { The front-stage } \\
\text { personnel are like } \\
\text { the members of a } \\
\text { cast, playing roles } \\
\text { as actors in a } \\
\text { drama, and } \\
\text { supported by a } \\
\text { back-stage } \\
\text { production team. } \\
\text { Lovelock and } \\
\text { Wirtz (2011:71) }\end{array}$} & $\begin{array}{l}\text { Keseragaman } \\
\text { pakaian yang } \\
\text { dikenakan instruktur } \\
\text { outbound. }\end{array}$ & $\begin{array}{l}\text { Tingkat } \\
\text { keseragaman } \\
\text { pakaian yang } \\
\text { dikenakan instruktur } \\
\text { outbound. }\end{array}$ & Ordinal & C.2.8 \\
\hline & & $\begin{array}{l}\text { Kemenarikan } \\
\text { seragam instruktur } \\
\text { outbound. }\end{array}$ & $\begin{array}{l}\text { Tingkat kemenarikan } \\
\text { seragam instruktur } \\
\text { outbound. }\end{array}$ & Ordinal & C.2.9 \\
\hline & & $\begin{array}{l}\text { Kemenarikan warna } \\
\text { seragam yang } \\
\text { dikenakan instruktur } \\
\text { outbound. }\end{array}$ & $\begin{array}{l}\text { Tingkat kemenarikan } \\
\text { warna seragam yang } \\
\text { dikenakan instruktur } \\
\text { outbound. }\end{array}$ & Ordinal & C.2.10 \\
\hline & & $\begin{array}{l}\text { Kerapihan seragam } \\
\text { yang dikenakan } \\
\text { instruktur outbound. }\end{array}$ & $\begin{array}{l}\text { Tingkat kerapihan } \\
\text { seragam yang } \\
\text { dikenakan instruktur } \\
\text { outbound. }\end{array}$ & Ordinal & C.2.11 \\
\hline & & $\begin{array}{l}\text { Keramahtamahan } \\
\text { instruktur outbound. }\end{array}$ & $\begin{array}{l}\text { Tingkat } \\
\text { keramahtamahan } \\
\text { instruktur outbound. }\end{array}$ & Ordinal & C.2.12 \\
\hline \multirow{4}{*}{ Roles $\left(\mathbf{X}_{3}\right)$} & \multirow{4}{*}{$\begin{array}{l}\text { A set of behavior } \\
\text { patterns learned } \\
\text { through experience } \\
\text { and communication, } \\
\text { to be performed by } \\
\text { an individual in a } \\
\text { certain social } \\
\text { interaction in order } \\
\text { to attain maximum } \\
\text { effectiveness in gol } \\
\text { acomplishment. } \\
\text { Lovelock and } \\
\text { Wirtz (2011:71) }\end{array}$} & $\begin{array}{l}\text { Kesesuaian peran } \\
\text { instruktur outbound } \\
\text { dalam menjalankan } \\
\text { tugasnya. }\end{array}$ & $\begin{array}{l}\text { Tingkat kesesuaian } \\
\text { peran instruktur } \\
\text { outbound dalam } \\
\text { menjalankan } \\
\text { tugasnya. }\end{array}$ & Ordinal & C.3.13 \\
\hline & & $\begin{array}{l}\text { Kesesuaian } \\
\text { penyampaian } \\
\text { informasi yang } \\
\text { diberikan instruktur } \\
\text { outbound. }\end{array}$ & $\begin{array}{l}\text { Tingkat kesesuaian } \\
\text { penyampaian } \\
\text { informasi yang } \\
\text { diberikan instruktur } \\
\text { outbound. }\end{array}$ & Ordinal & C.3.14 \\
\hline & & $\begin{array}{l}\text { Kesesuaian } \\
\text { tanggung jawab } \\
\text { instruktur outbound } \\
\text { dalam menjalankan } \\
\text { tugasnya. }\end{array}$ & $\begin{array}{l}\text { Tingkat kesesuaian } \\
\text { tanggung jawab } \\
\text { instruktur outbound } \\
\text { dalam menjalankan } \\
\text { tugasnya. }\end{array}$ & Ordinal & C.3.15 \\
\hline & & $\begin{array}{l}\text { Kesesuain } \\
\text { komunikasi } \\
\text { instruktur outbound } \\
\text { dengan wisatawan. }\end{array}$ & $\begin{array}{l}\text { Tingkat kesesuaian } \\
\text { komunikasi } \\
\text { instruktur outbound } \\
\text { dengan wisatawan. }\end{array}$ & Ordinal & C.3.16 \\
\hline \multirow{2}{*}{ Scripts $\left(\mathrm{X}_{4}\right)$} & \multirow{2}{*}{$\begin{array}{l}\text { Specifies the } \\
\text { sequences of } \\
\text { behavior for } \\
\text { customers and } \\
\text { employees are } \\
\text { expected to learn } \\
\text { and follow during } \\
\text { service delivery. } \\
\text { Lovelock and } \\
\text { Wirtz (2011:71) }\end{array}$} & $\begin{array}{l}\text { Kemampuan } \\
\text { instruktur outbound } \\
\text { pada saat } \\
\text { memberikan } \\
\text { greeting atau } \\
\text { sapaan. }\end{array}$ & $\begin{array}{l}\text { Tingkat kemampuan } \\
\text { instruktur outbound } \\
\text { pada saat } \\
\text { memberikan } \\
\text { greeting atau sapaan. }\end{array}$ & Ordinal & C.4.17 \\
\hline & & $\begin{array}{l}\text { Kemampuan } \\
\text { instruktur outbound } \\
\text { dalam memberikan } \\
\text { arahan mengenai } \\
\text { proses dan prosedur } \\
\text { outbound. }\end{array}$ & $\begin{array}{l}\text { Tingkat kemampuan } \\
\text { instruktur outbound } \\
\text { dalam memberikan } \\
\text { arahan mengenai } \\
\text { proses dan prosedur } \\
\text { outbound. }\end{array}$ & Ordinal & C.4.18 \\
\hline
\end{tabular}


Lanjutan Tabel 3.1

\begin{tabular}{|c|c|c|c|c|c|}
\hline $\begin{array}{l}\text { Variabel/Sub } \\
\text { Variabel }\end{array}$ & Konsep & Indikator & Ukuran & Skala & $\begin{array}{l}\text { No. Item } \\
\text { Pertanyaan }\end{array}$ \\
\hline & & $\begin{array}{l}\text { Kemampuan } \\
\text { berbahasa yang } \\
\text { dikuasai instruktur } \\
\text { outbound, termasuk } \\
\text { kemampuan bahasa } \\
\text { asing. }\end{array}$ & $\begin{array}{l}\text { Tingkat kemampuan } \\
\text { berbahasa yang } \\
\text { dikuasai instruktur } \\
\text { outbound, termasuk } \\
\text { kemampuan bahasa } \\
\text { asing. }\end{array}$ & Ordinal & C.4.19 \\
\hline & & $\begin{array}{l}\text { Tanggung jawab } \\
\text { instruktur outbound } \\
\text { pada saat } \\
\text { mendampingi } \\
\text { wisatawan. }\end{array}$ & $\begin{array}{l}\text { Tingkat rasa } \\
\text { tanggung jawab } \\
\text { instruktur outbound } \\
\text { pada saat } \\
\text { mendampingi } \\
\text { wisatawan. }\end{array}$ & Ordinal & C.4.20 \\
\hline & & $\begin{array}{l}\text { Kepedulian } \\
\text { instruktur outbound. }\end{array}$ & $\begin{array}{l}\text { Tingkat kepedulian } \\
\text { instruktur outbound. }\end{array}$ & Ordinal & C.4.21 \\
\hline & & $\begin{array}{l}\text { Kesigapan } \\
\text { instruktur outbound. }\end{array}$ & $\begin{array}{l}\text { Tingkat kesigapan } \\
\text { instruktur outbound. }\end{array}$ & Ordinal & C.4.22 \\
\hline & & $\begin{array}{l}\text { Kemampuan } \\
\text { instruktur outbound } \\
\text { dalam memberikan } \\
\text { penutupan } \\
\text { pelaksanaan } \\
\text { outbound. }\end{array}$ & $\begin{array}{l}\text { Tingkat kemampuan } \\
\text { instruktur outbound } \\
\text { dalam memberikan } \\
\text { penutupan } \\
\text { pelaksanaan } \\
\text { outbound. }\end{array}$ & Ordinal & C.4.23 \\
\hline Kepuasan (Y) & \multicolumn{5}{|c|}{$\begin{array}{c}\text { Customer satisfaction is the extent to which a product's perceived performance matches a } \\
\text { buyer's expectations. Kotler dan Amstrong (2012:37) }\end{array}$} \\
\hline \multirow{7}{*}{$\begin{array}{l}\text { Expectations } \\
\text { (Harapan) }\end{array}$} & & \multirow{7}{*}{ Service facilities } & $\begin{array}{l}\text { Tingkat harapan } \\
\text { keindahan landscape } \\
\text { di area outbound. }\end{array}$ & Ordinal & C.1.1 \\
\hline & & & $\begin{array}{l}\text { Tingkat harapan } \\
\text { kenyamanan lokasi } \\
\text { pelaksanaan } \\
\text { outbound. }\end{array}$ & Ordinal & C.1.2 \\
\hline & & & $\begin{array}{l}\text { Tingkat harapan } \\
\text { kebersihan area } \\
\text { outbound. }\end{array}$ & Ordinal & C.1.3 \\
\hline & & & $\begin{array}{l}\text { Tingkat harapan } \\
\text { kelengkapan fasilitas } \\
\text { alat-alat outbound. }\end{array}$ & Ordinal & C.1.4 \\
\hline & & & $\begin{array}{l}\text { Tingkat harapan } \\
\text { keamanan fasilitas } \\
\text { alat-alat outbound. }\end{array}$ & Ordinal & C.1.5 \\
\hline & & & $\begin{array}{l}\text { Tingkat harapan } \\
\text { kelayakan kondisi } \\
\text { fasilitas alat-alat } \\
\text { outbound. }\end{array}$ & Ordinal & C.1.6 \\
\hline & & & $\begin{array}{l}\text { Tingkat harapan } \\
\text { kenyamanan fasilitas } \\
\text { yang tersedia di area } \\
\text { outbound. }\end{array}$ & Ordinal & C.1.7 \\
\hline
\end{tabular}


Lanjutan Tabel 3.1

\begin{tabular}{|c|c|c|c|c|c|}
\hline $\begin{array}{c}\text { Variabel/Sub } \\
\text { Variabel } \\
\end{array}$ & Konsep & Indikator & Ukuran & Skala & $\begin{array}{c}\text { No. Item } \\
\text { Pertanyaan }\end{array}$ \\
\hline & & \multirow{5}{*}{ Personnel } & $\begin{array}{l}\text { Tingkat harapan } \\
\text { keseragaman } \\
\text { pakaian yang } \\
\text { dikenakan instruktur } \\
\text { outbound. }\end{array}$ & Ordinal & C.2.8 \\
\hline & & & $\begin{array}{l}\text { Tingkat harapan } \\
\text { kemenarikan } \\
\text { seragam instruktur } \\
\text { outbound. }\end{array}$ & Ordinal & C.2.9 \\
\hline & & & $\begin{array}{l}\text { Tingkat harapan } \\
\text { kemenarikan warna } \\
\text { seragam yang } \\
\text { dikenakan instruktur } \\
\text { outbound. }\end{array}$ & Ordinal & C.2.10 \\
\hline & & & $\begin{array}{l}\text { Tingkat harapan } \\
\text { kerapihan seragam } \\
\text { yang dikenakan } \\
\text { instruktur outbound. }\end{array}$ & Ordinal & C.2.11 \\
\hline & & & $\begin{array}{l}\text { Tingkat harapan } \\
\text { keramahtamahan } \\
\text { instruktur outbound. }\end{array}$ & Ordinal & C.2.12 \\
\hline & & \multirow{4}{*}{ Roles } & $\begin{array}{l}\text { Tingkat harapan } \\
\text { kesesuaian peran } \\
\text { instruktur outbound } \\
\text { dalam menjalankan } \\
\text { tugasnya. }\end{array}$ & Ordinal & C.3.13 \\
\hline & & & $\begin{array}{l}\text { Tingkat harapan } \\
\text { kesesuaian } \\
\text { penyampaian } \\
\text { informasi yang } \\
\text { diberikan instruktur } \\
\text { outbound. }\end{array}$ & Ordinal & C.3.14 \\
\hline & & & $\begin{array}{l}\text { Tingkat harapan } \\
\text { kesesuaian tanggung } \\
\text { jawab instruktur } \\
\text { outbound dalam } \\
\text { menjalankan } \\
\text { tugasnya. }\end{array}$ & Ordinal & C.3.15 \\
\hline & & & $\begin{array}{l}\text { Tingkat harapan } \\
\text { komunikasi } \\
\text { instruktur outbound } \\
\text { dengan wisatawan. }\end{array}$ & Ordinal & C.3.16 \\
\hline & & Scripts & $\begin{array}{l}\text { Tingkat harapan } \\
\text { kemampuan } \\
\text { instruktur outbound } \\
\text { pada saat } \\
\text { memberikan } \\
\text { greeting atau sapaan. }\end{array}$ & Ordinal & C.4.17 \\
\hline
\end{tabular}


Lanjutan Tabel 3.1

\begin{tabular}{|c|c|c|c|c|c|}
\hline $\begin{array}{c}\text { Variabel/Sub } \\
\text { Variabel }\end{array}$ & Konsep & Indikator & Ukuran & Skala & $\begin{array}{c}\text { No. Item } \\
\text { Pertanyaan }\end{array}$ \\
\hline & & & $\begin{array}{l}\text { Tingkat harapan } \\
\text { kemampuan } \\
\text { instruktur outbound } \\
\text { dalam memberikan } \\
\text { arahan mengenai } \\
\text { proses dan prosedur } \\
\text { outbound. }\end{array}$ & Ordinal & C.4.18 \\
\hline & & & $\begin{array}{l}\text { Tingkat harapan } \\
\text { kemampuan } \\
\text { berbahasa yang } \\
\text { dikuasai instruktur } \\
\text { outbound, termasuk } \\
\text { kemampuan bahasa } \\
\text { asing. }\end{array}$ & Ordinal & C.4.19 \\
\hline & & & $\begin{array}{l}\text { Tingkat harapan rasa } \\
\text { tanggung jawab } \\
\text { instruktur outbound } \\
\text { pada saat } \\
\text { mendampingi } \\
\text { wisatawan. }\end{array}$ & Ordinal & C.4.20 \\
\hline & & & $\begin{array}{l}\text { Tingkat harapan } \\
\text { kepedulian instruktur } \\
\text { outbound. }\end{array}$ & Ordinal & C.4.21 \\
\hline & & & $\begin{array}{l}\text { Tingkat harapan } \\
\text { kesigapan instruktur } \\
\text { outbound. }\end{array}$ & Ordinal & C.4.22 \\
\hline & & & $\begin{array}{l}\text { Tingkat harapan } \\
\text { kemampuan } \\
\text { instruktur outbound } \\
\text { dalam memberikan } \\
\text { penutupan } \\
\text { pelaksanaan } \\
\text { outbound. }\end{array}$ & Ordinal & C.4.23 \\
\hline \multirow{6}{*}{$\begin{array}{c}\text { Perceived } \\
\text { (Kenyataan) }\end{array}$} & & \multirow{6}{*}{ Service facilities } & $\begin{array}{l}\text { Tingkat kenyataan } \\
\text { keindahan landscape } \\
\text { di area outbound. }\end{array}$ & Ordinal & C.1.1 \\
\hline & & & $\begin{array}{l}\text { Tingkat kenyataan } \\
\text { kenyamanan lokasi } \\
\text { pelaksanaan } \\
\text { outbound. }\end{array}$ & Ordinal & C.1.2 \\
\hline & & & $\begin{array}{l}\text { Tingkat kenyataan } \\
\text { kebersihan area } \\
\text { outbound. }\end{array}$ & Ordinal & C.1.3 \\
\hline & & & $\begin{array}{l}\text { Tingkat kenyataan } \\
\text { kelengkapan fasilitas } \\
\text { alat-alat outbound. }\end{array}$ & Ordinal & C.1.4 \\
\hline & & & $\begin{array}{l}\text { Tingkat kenyataan } \\
\text { keamanan fasilitas } \\
\text { alat-alat outbound. }\end{array}$ & Ordinal & C.1.5 \\
\hline & & & $\begin{array}{l}\text { Tingkat kenyataan } \\
\text { kelayakan kondisi } \\
\text { fasilitas alat-alat } \\
\text { outbound. }\end{array}$ & Ordinal & C.1.6 \\
\hline
\end{tabular}


Lanjutan Tabel 3.1

\begin{tabular}{|c|c|c|c|c|c|}
\hline $\begin{array}{c}\text { Variabel/Sub } \\
\text { Variabel }\end{array}$ & Konsep & Indikator & Ukuran & Skala & $\begin{array}{c}\text { No. Item } \\
\text { Pertanyaan }\end{array}$ \\
\hline & & & $\begin{array}{l}\text { Tingkat kenyataan } \\
\text { kenyamanan fasilitas } \\
\text { yang tersedia di area } \\
\text { outbound. }\end{array}$ & Ordinal & C.1.7 \\
\hline & & \multirow{5}{*}{ Personnel } & $\begin{array}{l}\text { Tingkat kenyataan } \\
\text { keseragaman } \\
\text { pakaian yang } \\
\text { dikenakan instruktur } \\
\text { outbound. }\end{array}$ & Ordinal & C.2.8 \\
\hline & & & $\begin{array}{l}\text { Tingkat kenyataan } \\
\text { kemenarikan } \\
\text { seragam instruktur } \\
\text { outbound. }\end{array}$ & Ordinal & C.2.9 \\
\hline & & & $\begin{array}{l}\text { Tingkat kenyataan } \\
\text { kemenarikan warna } \\
\text { seragam yang } \\
\text { dikenakan instruktur } \\
\text { outbound. }\end{array}$ & Ordinal & C.2.10 \\
\hline & & & $\begin{array}{l}\text { Tingkat kenyataan } \\
\text { kerapihan seragam } \\
\text { yang dikenakan } \\
\text { instruktur outbound. }\end{array}$ & Ordinal & C.2.11 \\
\hline & & & $\begin{array}{l}\text { Tingkat kenyataan } \\
\text { keramahtamahan } \\
\text { instruktur outbound. }\end{array}$ & Ordinal & C.2.12 \\
\hline & & \multirow{4}{*}{ Roles } & $\begin{array}{l}\text { Tingkat kenyataan } \\
\text { kesesuaian peran } \\
\text { instruktur outbound } \\
\text { dalam menjalankan } \\
\text { tugasnya. }\end{array}$ & Ordinal & C.3.13 \\
\hline & & & $\begin{array}{l}\text { Tingkat kenyataan } \\
\text { kesesuaian } \\
\text { penyampaian } \\
\text { informasi yang } \\
\text { diberikan instruktur } \\
\text { outbound. }\end{array}$ & Ordinal & C.3.14 \\
\hline & & & $\begin{array}{l}\text { Tingkat kenyataan } \\
\text { tanggung jawab } \\
\text { instruktur outbound } \\
\text { dalam menjalankan } \\
\text { tugasnya. }\end{array}$ & Ordinal & C.3.15 \\
\hline & & & $\begin{array}{l}\text { Tingkat kenyataan } \\
\text { komunikasi } \\
\text { instruktur outbound } \\
\text { dengan wisatawan. }\end{array}$ & Ordinal & C.3.16 \\
\hline & & Scripts & $\begin{array}{l}\text { Tingkat kenyataan } \\
\text { kemampuan } \\
\text { instruktur outbound } \\
\text { pada saat } \\
\text { memberikan } \\
\text { greeting atau sapaan. }\end{array}$ & Ordinal & C.4.17 \\
\hline
\end{tabular}


Lanjutan Tabel 3.1

\begin{tabular}{|c|c|c|c|c|c|}
\hline $\begin{array}{c}\text { Variabel/Sub } \\
\text { Variabel }\end{array}$ & Konsep & Indikator & Ukuran & Skala & $\begin{array}{c}\text { No. Item } \\
\text { Pertanyaan }\end{array}$ \\
\hline & & & $\begin{array}{l}\text { Tingkat kenyataan } \\
\text { kemampuan } \\
\text { instruktur outbound } \\
\text { dalam memberikan } \\
\text { arahan mengenai } \\
\text { proses dan prosedur } \\
\text { outbound. }\end{array}$ & Ordinal & C.4.18 \\
\hline & & & $\begin{array}{l}\text { Tingkat kenyataan } \\
\text { kemampuan } \\
\text { berbahasa yang } \\
\text { dikuasai instruktur } \\
\text { outbound, termasuk } \\
\text { kemampuan bahasa } \\
\text { asing. }\end{array}$ & Ordinal & C.4.19 \\
\hline & & & $\begin{array}{l}\text { Tingkat kenyataan } \\
\text { rasa tanggung jawab } \\
\text { instruktur outbound } \\
\text { pada saat } \\
\text { mendampingi } \\
\text { wisatawan. }\end{array}$ & Ordinal & C.4.20 \\
\hline & & & $\begin{array}{l}\text { Tingkat kenyataan } \\
\text { kepedulian instruktur } \\
\text { outbound. }\end{array}$ & Ordinal & C.4.21 \\
\hline & & & $\begin{array}{l}\text { Tingkat kenyataan } \\
\text { kesigapan instruktur } \\
\text { outbound. }\end{array}$ & Ordinal & C. 4.22 \\
\hline & & & $\begin{array}{l}\text { Tingkat kenyataan } \\
\text { kemampuan } \\
\text { instruktur outbound } \\
\text { dalam memberikan } \\
\text { penutupan } \\
\text { pelaksanaan } \\
\text { outbound. }\end{array}$ & Ordinal & C.4.23 \\
\hline
\end{tabular}

Sumber: Hasil pengolahan Data, 2012

\subsubsection{Metode Penarikan Sampel}

Sampel dalam penelitian ini yaitu sebagian dari populasi wisatawan yang menggunakan paket outbound di Objek Wisata Linggarjati Indah Kabupaten Kuningan. Dalam penelitian ini sampel sebanyak 100 wisatawan dari jumlah wisatawan sebanyak 52.386. dengan penghitungan proportionate stratified random sampling. Teknik ini digunakan bila populasi mempunyai anggota/unsur yang tidak homogen dan berstrata secara proporsional (Sugiyono, 2010:118).

\subsubsection{Prosedur Pengumpulan Data}

Pengumpulan data yang dilakukan penulis menggunakan teknik sebagai berikut:

1. Wawancara

2. Kuesioner

3. Studi Literatur

4. Observasi

\subsection{Hasil Pengujian Validitas dan} Reliabilitas

\subsubsection{Hasil Pengujian Validitas}

Berdasarkan hasil pengolahan data dengan menggunakan software komputer SPSS 18 menunjukkan bahwa item-item pertanyaan dalam kuesioner valid karena $\mathrm{r}_{\text {hitung }}$ lebih besar jika dibandingkan dengan $\mathrm{r}_{\text {tabel }}$ yang bernilai 0,374 .

\subsubsection{Hasil Pengujian Reabilitas}

Hasil pengujian reliabilitas service delivery yang terdiri dari service facilities, personnel, roles dan scripts dengan kepuasan. Pengujian tersebut menggunakan SPSS 18 dengan model product moment (Pearson) dapat dikatakan reliabel. Hal tersebut dikarenakan nilai reliabiliatas untuk kedua variabel tersebut sebesar 0,794 dan 0,816 lebih besar dari nilai minimal yaitu 0.70 . 


\subsection{Pengujian Hipotesis}

Teknik untuk menguji data yang digunakan dalam penelitian kuantitatif ini adalah metode analisis verifikatif. maka dilakukan analisis regresi berganda.

Berdasarkan tujuan penelitian ini, maka variabel yang dianalisis adalah variabel independen yaitu service delivery yang terdiri service facilities, personnel, roles, dan scripts. Sedangkan variabel dependen adalah kepuasan wisatawan. Untuk bisa membuat ramalan melalui regresi, maka data setiap variabel harus tersedia. Berdasarkan data tersebut peneliti harus menemukan persamaan regresi berganda melalui perhitungan sebagai berikut:

$\mathrm{Y}=\mathrm{a}+\mathrm{bX} 1.1+\mathrm{bX} 1.2+\mathrm{bX} 1.3+\mathrm{bX} 1.4$

\section{Keterangan:}

$\mathrm{Y}=$ Subyek dalam variabel dependen yang diprediksikan (kepuasan wisatawan)

$\mathrm{a}=$ Harga $\mathrm{Y}$ bila $\mathrm{X}=0$

$\mathrm{b}=$ Angka arah atau koefisien regresi, yang menunjukan angka peningkatan ataupun penurunan variabel dependen yang didasarkan pada variabel independen. Bila $b$ (+) maka naik, dan bila (-) maka terjadi penurunan.

$X=$ Subyek pada variabel independen yang mempunyai nilai tertentu. X1, X2, X3, X4 = variabel penyebab $(\mathrm{X} 1=$ service facilities $)$, $(\mathrm{X} 2=$ personnel $),(\mathrm{X} 3=$ roles $)$ dan $(\mathrm{X} 4=$ scripts).

Analisis regresi berganda akan dilakukan bila jumlah variabel independen minimal dua atau lebih. Menerjemahkan ke dalam beberapa sub hipotesis yang menyatakan pengaruh sub variabel independen yang paling dominan terhadap variabel dependen, lebih jelasnya dapat dilihat pada Gambar 3.1 berikut :

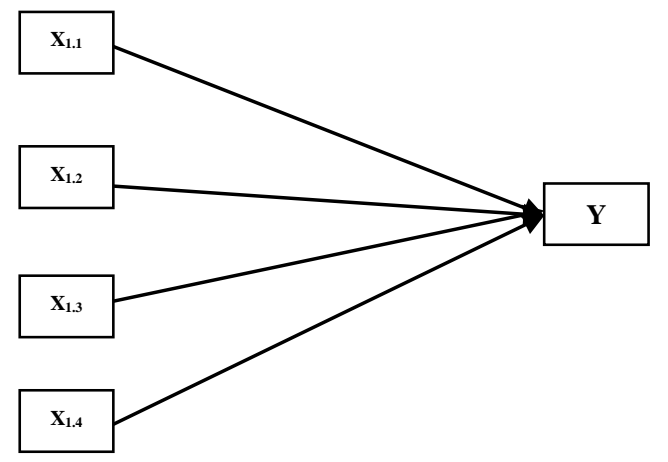

GAMBAR 3.1 REGRESI BERGANDA
Dalam hal ini dilakukan pengujian hipotesis secara silmutan dan parsial.

1. Pengujian Hipotesis Secara Simultan Kriteria pengujian untuk hipotesis yang dilakukan secara simultan adalah sebagai berikut:

Jika $\mathrm{F}_{\text {hitung }}>\mathrm{F}_{\text {tabel }}$ maka $\mathrm{H}_{0}$ ditolak dan $\mathrm{H}_{\mathrm{i}}$ diterima.

Ho : Pyx $=0$;

Tidak terdapat pengaruh yang signifikan antara service delivery yang terdiri dari service facilities, personnel, roles, dan scripts terhadap kepuasan wisatawan dalam menggunakan paket outbound di Objek Wisata Linggarjati Indah Kabupaten Kuningan.

Hi : Pyx $\neq 0$;

Terdapat pengaruh yang signifikan antara service delivery yang terdiri dari service facilities, personnel, roles, dan scripts terhadap kepuasan wisatawan dalam menggunakan paket outbound di Objek Wisata Linggarjati Indah Kabupaten Kuningan.

2. Pengujian Hipotesis Secara Parsial

Kriteria pengujian untuk hipotesis yang dilakukan secara parsial adalah sebagai berikut:

1) Jika $t_{\text {hitung }}>t_{\text {tabel }}$, dengan nilai signifikansi $<0,05$, maka Ho ditolak dan Hi diterima.

$\mathrm{H}_{\mathrm{o}}=0$, Tidak terdapat pengaruh yang signifikan antara service facilities dengan kepuasan wisatawan yang menggunakan paket outbound di Objek Wisata Linggarjati Indah Kabupaten Kuningan.

$\mathrm{H}_{\mathrm{i}} \neq 0$, Terdapat pengaruh signifikan antara service facilities dengan kepuasan wisatawan yang menggunakan paket outbound di Objek Wisata Linggarjati Indah Kabupaten Kuningan.

2) Jika $t_{\text {hitung }}>t_{\text {tabel }}$ dengan nilai signifikansi $<0,05$, maka $\mathrm{H}_{0}$ ditolak dan $\mathrm{H}_{\mathrm{i}}$ diterima.

$\mathrm{H}_{\mathrm{o}}=0$, Tidak terdapat pengaruh yang signifikan antara personnel dengan kepuasan wisatawan yang menggunakan paket outbound di Objek Wisata Linggarjati Indah Kabupaten Kuningan.

$\mathrm{H}_{\mathrm{i}} \neq 0$, Terdapat pengaruh signifikan antara personnel dengan kepuasan wisatawan yang menggunakan paket outbound di Objek Wisata 
Linggarjati Indah Kabupaten Kuningan.

3) Jika $t_{\text {hitung }}>t_{\text {tabel }}$ dengan nilai signifikansi $<0,05$, maka $\mathrm{H}_{0}$ ditolak dan $\mathrm{H}_{\mathrm{i}}$ diterima.

$\mathrm{H}_{\mathrm{o}}=0$, Tidak terdapat pengaruh yang signifikan antara roles dengan kepuasan wisatawan yang menggunakan paket outbound di Objek Wisata Linggarjati Indah Kabupaten Kuningan.

$\mathrm{H}_{\mathrm{i}} \neq 0$, Terdapat pengaruh signifikan antara roles dengan kepuasan wisatawan yang menggunakan paket outbound di Objek Wisata Linggarjati Indah Kabupaten Kuningan.

\section{HASIL PENELITIAN DAN} PEMBAHASAN

4.1 Gambaran Service Delivery di Objek Wisata Linggarjati Indah Kabupaten Kuningan

Berdasarkan pengolahan data yang dilakukan, maka berikut ini rekapitulasi tanggapan wisatawan Objek Wisata
4) Jika $t_{\text {hitung }}>t_{\text {tabel }}$ dengan nilai signifikansi $<0,05$, maka $\mathrm{H}_{0}$ ditolak dan $\mathrm{H}_{\mathrm{i}}$ diterima.

$\mathrm{H}_{\mathrm{o}}=0$, Tidak terdapat pengaruh yang signifikan antara scripts dengan kepuasan wisatawan yang menggunakan paket outbound di Objek Wisata Linggarjati Indah Kabupaten Kuningan.

$\mathrm{H}_{\mathrm{i}} \neq 0$, Terdapat pengaruh signifikan antara scripts dengan kepuasan wisatawan yang menggunakan paket outbound di Objek Wisata Linggarjati Indah Kabupaten Kuningan.
Linggarjati Indah Kabupaten Kuningan mengenai program service delivery yang diterima (perceived).

TABEL 4.1

REKAPITULASI TANGGAPAN WISATAWAN OBJEK WISATA LINGGARJATI INDAH KABUPATEN KUNINGAN MENGENAI PROGRAM SERVICE DELIVERYYANG DITERIMA (PERCEIVED)

\begin{tabular}{|c|c|c|c|}
\hline No & Dimensi & Perolehan Total Skor & $\%$ \\
\hline 1 & Service Facilities & 3010 & $30,4 \%$ \\
\hline 2 & Personnel & 2190 & $22,2 \%$ \\
\hline 3 & Roles & 1685 & $17 \%$ \\
\hline 4 & Scripts & 3001 & $30,3 \%$ \\
\hline \multicolumn{2}{|c|}{ Total } & 9886 & $100 \%$ \\
\hline
\end{tabular}

Tabel 4.1 menunjukkan bahwa dimensi service delivery yang mendapatkan penilaian skor paling besar yaitu pada service facilities sebanyak 30,4\%, scripts sebanyak 30,3\%, personnel sebesar $22,2 \%$ dan roles sebesar $17 \%$. Tingginya skor yang diperoleh service facilities dikarenakan fasilitas merupakan hal pertama yang diperhatikan oleh wisatawan saat mengunjungi.
Berdasarkan pengolahan data yang dilakukan, maka berikut ini rekapitulasi tanggapan wisatawan Objek Wisata Linggarjati Indah Kabupaten Kuningan mengenai program service delivery yang diharapkan (expected). 
TABEL 4.2

REKAPITULASI TANGGAPAN WISATAWAN OBJEK WISATA LINGGARJATI INDAH KABUPATEN KUNINGAN MENGENAI PROGRAM SERVICE DELIVERY YANG DIHARAPKAN (EXPECTED)

\begin{tabular}{|c|l|c|c|}
\hline No & \multicolumn{1}{|c|}{ Dimensi } & Perolehan Total Skor & \% \\
\hline 1 & Service Facilities & 3077 & $30,7 \%$ \\
\hline 2 & Personnel & 2225 & $22,2 \%$ \\
\hline 3 & Roles & 1708 & $17 \%$ \\
\hline 4 & Scripts & 3017 & $30,1 \%$ \\
\hline \multicolumn{2}{|c|}{ Total } & 10027 & $100 \%$ \\
\hline
\end{tabular}

Sumber : Hasil Pengolahan Data Primer, 2012

Tabel 4.2 menunjukkan bahwa dimensi service delivery yang mendapatkan penilaian skor paling besar yaitu pada service facilities sebanyak $30,7 \%$, scripts sebesar $30,1 \%$, kemudian, personnel sebesar $22,2 \%$ dan roles sebesar $17 \%$. Tingginya skor yang diperoleh service facilities dikarenakan fasilitas merupakan hal pertama yang diharapkan dapat memberikan kepuasan oleh wisatawan saat menggunakan paket outbound di Objek Wisata Linggarjati Indah Kabupaten Kuningan.

4.2 Gambaran Kepuasan Wisatawan yang Menggunakan Paket Outbound di Objek Wisata Linggarjati Indah Kabupaten Kuningan

Pada penelitian ini, untuk mengetahui tingkat kepuasan wisatawan yang menggunakan paket outbound di Objek Wisata Linggarjati Indah Kabupaten Kuningan menggunakan Customer Satisfaction Index (CSI) yaitu dengan pendekatan yang mempertimbangkan tingkat harapan dari atribut-atribut service delivery yang diukur.

Berdasarkan hasil pengolahan data dari angket yang telah disebarkan kepada 100 wisatawan yang menggunakan paket outbound di Objek Wisata Linggarjati Indah Kabupaten Kuningan mengenai kepuasan wisatawan. Secara keseluruhan tanggapan wisatawan yang menggunakan paket outbound di Objek Wisata Linggarjati Indah Kabupaten Kuningan dapat dilihat dari sub variabel sebagai berikut:

TABEL 4.3

TANGGAPAN WISATAWAN YANG MENGGUNAKAN PAKET OUTBOUND DI OBJEK WISATA LINGGARJATI INDAH KABUPATEN KUNINGAN TERHADAP KEPUASAN DARI PROGRAM SERVICE DELIVERY

\begin{tabular}{|c|l|c|c|c|c|}
\hline No. & \multicolumn{1}{|c|}{ Sub Variabel } & $\begin{array}{c}\text { Rata-Rata Tingkat } \\
\text { Harapan }\end{array}$ & $\begin{array}{c}\text { Weighting } \\
\text { Factors (WF) }\end{array}$ & $\begin{array}{c}\text { Rata-Rata Tingkat } \\
\text { Kenyataan }\end{array}$ & $\begin{array}{c}\text { Weighted Score } \\
\text { (WS) }\end{array}$ \\
\hline \multicolumn{2}{|c|}{ Service Facilities } \\
\hline 1. & $\begin{array}{l}\text { Keindahan } \\
\text { landscape di area } \\
\text { outbound. }\end{array}$ & 4,76 & $4,75 \%$ & 4,59 & 0,22 \\
\hline 2. & $\begin{array}{l}\text { Kenyamanan lokasi } \\
\text { pelaksanaan } \\
\text { outbound. }\end{array}$ & 4,46 & $4,45 \%$ & 4,35 & 0,19 \\
\hline 3. & $\begin{array}{l}\text { Kebersihan area } \\
\text { outbound. }\end{array}$ & 4,22 & $4,21 \%$ & 4,14 & 0,17 \\
\hline
\end{tabular}


Lanjutan Tabel 4.3

\begin{tabular}{|c|c|c|c|c|c|}
\hline No. & Sub Variabel & $\begin{array}{c}\text { Rata-Rata Tingkat } \\
\text { Harapan }\end{array}$ & $\begin{array}{c}\text { Weighting } \\
\text { Factors (WF) }\end{array}$ & $\begin{array}{c}\text { Rata-Rata Tingkat } \\
\text { Kenyataan }\end{array}$ & $\begin{array}{c}\text { Weighted Score } \\
\text { (WS) }\end{array}$ \\
\hline \multicolumn{6}{|c|}{ Service Facilities } \\
\hline 4. & $\begin{array}{l}\text { Kelengkapan } \\
\text { fasilitas alat-alat } \\
\text { outbound. }\end{array}$ & 4,21 & $4,20 \%$ & 4,14 & 0,17 \\
\hline 5. & $\begin{array}{l}\text { Keamanan fasilitas } \\
\text { alat-alat outbound. }\end{array}$ & 4,26 & $4,25 \%$ & 4,24 & 0,18 \\
\hline 6. & $\begin{array}{l}\text { Kelayakan kondisi } \\
\text { fasilitas alat-alat } \\
\text { outbound. }\end{array}$ & 4,52 & $4,51 \%$ & 4,41 & 0,20 \\
\hline 7. & $\begin{array}{l}\text { Kenyamanan } \\
\text { fasilitas yang } \\
\text { tersedia di area } \\
\text { outbound. }\end{array}$ & 4,34 & $4,33 \%$ & 4,23 & 0,18 \\
\hline \multicolumn{6}{|c|}{ Personnel } \\
\hline 8. & $\begin{array}{l}\text { Keseragaman } \\
\text { pakaian yang } \\
\text { dikenakan instruktur } \\
\text { outbound. }\end{array}$ & 4,6 & $4,59 \%$ & 4,4 & 0,20 \\
\hline 9. & $\begin{array}{l}\text { Kemenarikan } \\
\text { seragam instruktur } \\
\text { outbound. }\end{array}$ & 4,41 & $4.40 \%$ & 4,38 & 0,19 \\
\hline 10 & $\begin{array}{l}\text { Kemenarikan warna } \\
\text { seragam yang } \\
\text { dikenakan instruktur } \\
\text { outbound. }\end{array}$ & 4,27 & $4,26 \%$ & 4,24 & 0,18 \\
\hline 11. & $\begin{array}{l}\text { Kerapihan seragam } \\
\text { yang dikenakan } \\
\text { instruktur outbound. }\end{array}$ & 4,51 & $4,50 \%$ & 4,39 & 0,20 \\
\hline 12. & $\begin{array}{l}\text { Keramahtamahan } \\
\text { instruktur outbound. }\end{array}$ & 4,46 & $4,45 \%$ & 4,49 & 0,20 \\
\hline \multicolumn{6}{|c|}{ Roles } \\
\hline 13. & $\begin{array}{l}\text { Kesesuaian peran } \\
\text { instruktur outbound } \\
\text { dalam menjalankan } \\
\text { tugasnya. }\end{array}$ & 4,2 & $4,19 \%$ & 4,14 & 0,17 \\
\hline 14. & $\begin{array}{l}\text { Kesesuaian } \\
\text { penyampaian } \\
\text { informasi yang } \\
\text { diberikan instruktur } \\
\text { outbound. }\end{array}$ & 4,49 & $4,48 \%$ & 4,29 & 0,19 \\
\hline 15 . & $\begin{array}{l}\text { Kesesuaian } \\
\text { tanggung jawab } \\
\text { instruktur outbound } \\
\text { dalam menjalankan } \\
\text { tugasnya. }\end{array}$ & 4,23 & $4,22 \%$ & 4,19 & 0,18 \\
\hline 16. & $\begin{array}{l}\text { Kesesuaian } \\
\text { komunikasi } \\
\text { instruktur outbound } \\
\text { dengan wisatawan. }\end{array}$ & 4,16 & $4,15 \%$ & 4,23 & 0,18 \\
\hline \multicolumn{6}{|c|}{ Scripts } \\
\hline 17. & $\begin{array}{l}\text { Kemampuan } \\
\text { instruktur outbound } \\
\text { pada saat } \\
\text { memberikan } \\
\text { greeting atau sapaan. }\end{array}$ & 4,47 & $4,46 \%$ & 4,49 & 0,20 \\
\hline 18. & $\begin{array}{l}\text { Kemampuan } \\
\text { instruktur outbound } \\
\text { dalam memberikan } \\
\text { arahan mengenai } \\
\text { proses dan prosedur } \\
\text { outbound. }\end{array}$ & 4,14 & $4,13 \%$ & 4,17 & 0,17 \\
\hline
\end{tabular}


Lanjutan Tabel 4.3

\begin{tabular}{|c|c|c|c|c|c|}
\hline No. & Sub Variabel & $\begin{array}{c}\text { Rata-Rata Tingkat } \\
\text { Harapan }\end{array}$ & $\begin{array}{c}\text { Weighting } \\
\text { Factors (WF) }\end{array}$ & $\begin{array}{c}\text { Rata-Rata Tingkat } \\
\text { Kenyataan }\end{array}$ & $\begin{array}{c}\text { Weighted Score } \\
\text { (WS) }\end{array}$ \\
\hline \multicolumn{6}{|c|}{ Scripts } \\
\hline 19. & $\begin{array}{l}\text { Kemampuan } \\
\text { berbahasa yang } \\
\text { dikuasai instruktur } \\
\text { outbound, termasuk } \\
\text { kemampuan bahasa } \\
\text { asing. }\end{array}$ & 4,21 & $4,20 \%$ & 4,12 & 0,17 \\
\hline 20. & $\begin{array}{l}\text { Tanggung jawab } \\
\text { instruktur outbound } \\
\text { pada saat } \\
\text { mendampingi } \\
\text { wisatawan. }\end{array}$ & 4,42 & $4,41 \%$ & 4,34 & 0,19 \\
\hline 21. & $\begin{array}{l}\text { Kepedulian } \\
\text { instruktur outbound. }\end{array}$ & 4,44 & $4,43 \%$ & 4,37 & 0,19 \\
\hline 22. & $\begin{array}{l}\text { Kesigapan instruktur } \\
\text { outbound. }\end{array}$ & 4,06 & $4,05 \%$ & 4,09 & 0,17 \\
\hline 23. & $\begin{array}{l}\text { Kemampuan } \\
\text { instruktur outbound } \\
\text { dalam memberikan } \\
\text { penutupan } \\
\text { pelaksanaan } \\
\text { outbound. }\end{array}$ & 4,43 & $4,42 \%$ & 4,43 & 0,20 \\
\hline \multicolumn{2}{|c|}{ TOTAL } & 100,27 & $100 \%$ & 98,86 & \\
\hline \multicolumn{2}{|c|}{ Weighted Total } & & & & 4,30 \\
\hline \multicolumn{2}{|c|}{ Satisfaction Index } & & & & $86 \%$ \\
\hline
\end{tabular}

Sumber: Hasil Pengolahan Data, 2012

Hasil Customer Satisfaction Index (CSI) yaitu sebesar $86 \%$, yang berarti tingkat kepuasan terletak diantara selang 0,81-1,00 yang berarti wisatawan yang menggunakan paket outbound sangat puas terhadap program service delivery di Objek Wisata Linggarjati Indah Kabupaten Kuningan secara keseluruhan.

\subsection{Pengaruh Service Delivery terhadap Kepuasan Wisatawan yang Menggunakan Paket Outbound di Objek Wisata Linggarjati Indah Kabupaten Kuningan}

\subsubsection{Hasil Uji Asumsi Variabel}

\section{Hasil Uji Asumsi Normalitas}

Syarat pertama untuk melakukan analisis regresi berganda adalah normalitas, sebagaimana yang diungkapkan oleh Suharsimi Arikunto (2010: 357) bahwa data sampel hendaknya memenuhi prasyarat distribusi normal. Uji normalitas dimaksud untuk mengetahui apakah residual yang diteliti berdistribusi normal atau tidak. Nilai residual berdistribusi normal merupakan satu kurva bentuk lonceng (bell-shapeedcurve) yang kedua sisinya melebur sampai tidak terhingga. Distribusi data tidak normal, karena terdapat nilai ekstrem dalam data yang diambil. Data yang mengandung data ekstrim biasanya tidak memenuhi asumsi normalitas. Jika sebaran data mengikuti sebaran normal, maka populasi dari mana data diambil berdistribusi normal dan akan dianalisis menggunakan analisis parametik. Cara mendeteksinya dengan menggunakan histogram regression residual yang sudah distandarkan serta menggunakan analisis kai kuadrat $\left(\mathrm{X}^{2}\right)$ dan kolmogorovsmirnov. Berikut gambar histogram dependent variabel kepuasan wisatawan yang menggunakan paket outbound di Objek Wisata Linggarjati Indah Kabupaten Kuningan. 
Histogram

Dependent Variable: $Y$

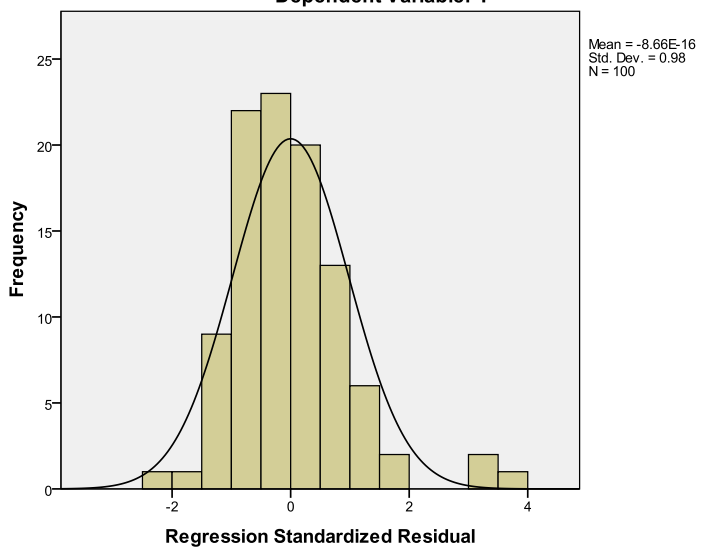

GAMBAR 4.1

HISTOGRAM DEPENDENT VARIABLE

KEPUASAN WISATAWAN YANG MENGGUNAKAN PAKET OUTBOUND DI OBJEK WISATA LINGGARJATI INDAH KABUPATEN KUNINGAN

Gambar 4.1 dapat dikatakan bahwa model berdistribusi normal karena kurva membetuk lonceng. Pengujian ini dilakukan dengan menggunakan normal probability plot. Melalui plot ini, masingmasing nilai pengamatan dipasangkan dengan nilai harapan dari distribusi normal apabila sebaran data terletak di sekitar garis lurus yang melalui titik nol dan tidak mempunyai pola. Gambar 4.2 nilai residu berdistribusi normal apabila sebaran datanya terletak di sekitar garis diagonal yaitu kiri bawah ke kanan atas. Dengan demikian berdasarkan Gambar 4.2 data memenuhi asumsi normalitas.

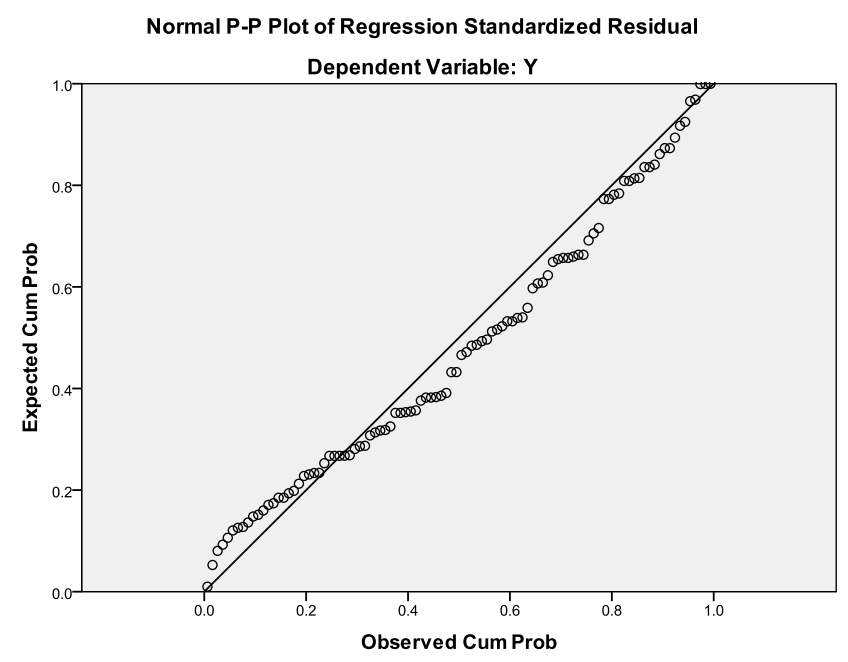

GAMBAR 4.2

NORMAL PROBABILITY PLOT 


\section{Hasil Uji Asumsi Heteroskedastisitas}

Heteroskedastisitas adalah varian residual yang tidak konstan pada regresi sehingga akurasi hasil prediksi menjadi meragukan. Residu pada heteroskedastisitas semakin besar apabila pengamatan semakin besar. Suatu regresi dikatakan tidak terdeteksi heteroskedastisitas apabila diagram pencar residualnya tidak membentuk pola tertentu dan apabila datanya terpencar disekitar angka 35 (pada sumbu Y).

Scatterplot



\section{GAMBAR 4.3 \\ UJI ASUMSI HETEROSKEDASTISITAS}

Berdasarkan gambar hasil uji diatas, dapat dilihat bahwa sebaran dimulai dari sebelah kiri bawah kearah kanan jika dilihat sebaran data tersebut, maka dapat dilihat sebaran data sudah mengikuti persyaratan model keseluruhan tiap data. Kesimpulannya adalah model regresi ini layak untuk digunakan untuk memprediksi kepuasan wisatawan yang menggunakan paket outbound di Objek Wisata Linggarjati Indah Kabupaten Kuningan.
3. Hasil Uji Asumsi Multikolinearitas

Multikolinearitas adalah kondisi dimana terdapat korelasi linier yang sempurna diantara variabel-variabel di dalam model. Pengujian dilakukan dengan melihat nilai VIF (Variance Inflation Factor), menurut Duwi Priyanto (2011:288), apabila nilai VIF<10 berarti tidak terjadi multikolinearitas. Hasil pengujian multikolinearitas adalah sebagai berikut:

TABEL 4.4

HASIL UJI MULTIKOLINEARITAS

\begin{tabular}{|c|c|c|}
\hline Variabel Bebas & VIF & Keterangan \\
\hline Service Facilities (X1) & 2.599 & Non multikolinearitas \\
Personnel (X2) & 2.459 & Non multikolinearitas \\
Roles (X3) & 1.472 & Non multikolinearitas \\
Scripts (X4) & 1.371 & Non multikolinearitas \\
\hline
\end{tabular}

Sumber: Hasil Pengolahan Data Primer, 2012

\subsubsection{Koefisien Korelasi dan Determinasi} Untuk mengetahui seberapa kuat hubungan dan seberapa besar pengaruh service delivery yang terdiri dari service facilities (X1), personnel (X2), scripts (X3), dan roles (X4). Secara bersama-sama dalam menjelaskan variabel kepuasan wisatawan dapat diteliti melalui nilai koefisien korelasi dan determinasi yang ditampilkan pada Tabel 4.5 berikut: 
TABEL 4.5

OUTPUT PENGARUH SERVICE DELIVERY

TERHADAP KEPUASAN WISATAWAN YANG MENGGUNAKAN PAKET OUTBOUND DI OBJEK WISATA LINGGARJATI INDAH KABUPATEN KUNINGAN

\begin{tabular}{|l|r|r|r|c|}
\hline Model & $\mathrm{R}$ & $\mathrm{R}$ Square & $\begin{array}{c}\text { Adjusted R } \\
\text { Square }\end{array}$ & $\begin{array}{c}\text { Std. Error of the } \\
\text { Estimate }\end{array}$ \\
\hline 1 & $.627^{\mathrm{a}}$ & .393 & .367 & 1.925778 \\
\hline
\end{tabular}

a. Predictors: (Constant), X4, X2, X3, X1

b. Dependent Variable: Y

Sumber: Hasil Pengolahan Data Primer, 2012

Berdasarkan Tabel 4.5 diperoleh nilai $\mathrm{R}$ $=0,627$. Hal ini menunjukan bahwa terdapat pengaruh antara service delivery yang terdiri dari service facilities (X1), personnel (X2), roles (X3) dan scripts (X4) terhadap kepuasan wisatawan (Y) yaitu 0,627. Maka korelasi antara service delivery yang terdiri dari service facilities (X1), personnel (X2), roles (X3) dan scripts (X4) terhadap kepuasan wisatawan termasuk kategori kuat (0,60-0,799), hal tersebut sesuai dengan interpretasi koefisien korelasi menurut Sugiyono (2010:231).

Berdasarkan hasil perhitungan, nilai koefisien determinasi adalah 0,367 atau
$36,7 \%$. Hal ini menunjukkan bahwa variabel service delivery terhadap kepuasan wisatawan (Y) secara bersama-sama menjelaskan variabel kepuasan wisatawan (Y) sebesar 36,7\%, sedangkan sisanya sebesar $63,3 \%$ dijelaskan oleh variabel lain yang tidak diteliti dalam penelitian ini.

\subsubsection{Pengujian Hipotesis dan Uji} Signifikansi Secara Simultan (Uji F) Untuk menguji signifikansi dapat digunakan uji $\mathrm{F}$, untuk lebih jelasnya mengenai output ANOVA dapat dilihat pada Tabel 4.6 berikut.

TABEL 4.6

OUTPUT ANOVA

\begin{tabular}{|ll|r|r|r|r|r|}
\hline \multicolumn{1}{|c|}{ Model } & & Sum of Squares & Df & Mean Square & F & Sig. \\
\hline 1 & Regression & 227.918 & 4 & 56.979 & 15.364 & $.000^{\mathbf{a}}$ \\
& Residual & 352.319 & 95 & 3.709 & & \\
& Total & 580.237 & 99 & & & \\
\hline
\end{tabular}

a. Predictors: (Constant), X4, X2, X3, X1

b. Dependent Variable: Y

Sumber: Hasil Pengolahan Data Primer, 2012

Berdasarkan Tabel 4.27 diatas, diperoleh nilai $F_{\text {hitung }}=15,364$, sedangkan $F_{\text {tabel }}$ dengan derajat kebebasan pada $\alpha(0,05)$ adalah sebesar 2,46. Dengan demikian $F_{\text {hitung }}$ $>\quad F_{\text {tabel }}(15,364>2,46)$ dengan nilai signifikansinya 0,000 . Nilai signifikansi lebih kecil dari tarif signifikansi 5\% sehingga jelas maka regresi dapat digunakan untuk memprediksi kepuasan wisatawan yang menggunakan paket outbound di Objek Wisata Linggarjati Indah Kabupaten Kuningan, sehingga Ho jelas ditolak dan $\mathrm{Hi}$ diterima. Hipotesis dalam penelitian ini sebagai berikut:

Hi : Pyx $\neq 0$;

Terdapat pengaruh yang signifikan antara service delivery yang terdiri dari service facilities, personnel, roles, dan scripts terhadap kepuasan wisatawan dalam menggunakan paket outbound di Objek Wisata Linggarjati Indah Kabupaten Kuningan 


\subsubsection{Pengujian Hipotesis dan Uji Signifikansi Secara Parsial (Uji t)}

Pengujian ini bertujuan untuk melihat pengaruh antara masing-masing variable independen mempengaruhi variabel dependen signifikan atau tidak dan untuk mencari informasi dari keseluruhan variabel bebas yaitu service delivery, variabel mana yang pengaruhnya paling dominan atau paling besar. Untuk tujuan ini dapat dilihat melalui tabel koefisien regresi berikut ini:

TABEL 4.7

OUTPUT KOEFISIEN REGRESI

Coefficients

\begin{tabular}{|c|c|c|c|c|c|c|}
\hline \multirow{2}{*}{\multicolumn{2}{|c|}{ Model }} & \multicolumn{2}{|c|}{ Unstandardized Coefficients } & $\begin{array}{l}\text { Standardized } \\
\text { Coefficients }\end{array}$ & \multirow[b]{2}{*}{$\mathrm{T}$} & \multirow[b]{2}{*}{ Sig. } \\
\hline & & B & Std. Error & Beta & & \\
\hline \multirow[t]{5}{*}{1} & (Constant) & 24.074 & .366 & & 65.793 & .000 \\
\hline & $\mathrm{X} 1$ & -.043 & .073 & -.075 & -.584 & .561 \\
\hline & $\mathrm{X} 2$ & .479 & .103 & .580 & 4.629 & .000 \\
\hline & $\mathrm{X} 3$ & .225 & .099 & .220 & 2.270 & .025 \\
\hline & $\mathrm{X} 4$ & -.012 & .049 & -.023 & -.246 & .807 \\
\hline
\end{tabular}

a. Dependent Variable: $\mathrm{Y}$

Sumber: Hasil Pengolahan Data Primer, 2012

Berdasarkan Tabel 4.7 diatas, secara parsial menunjukan bahwa variabel bebas (service delivery) tidak semua memiliki nilai signifikan yang lebih dari 0,05 . Hal ini dapat dijelaskan secara rinci sebagai berikut:

1. Hasil uji t parsial dapat diketahui bahwa nilai $\mathrm{t}$ hitung untuk dimensi service facilities (X1) sebesar $-0,584<1,960$, ini berarti bahwa tidak terdapat pengaruh yang signifikan antara dimensi service facilities dengan kepuasan.

2. Hasil uji t parsial dapat diketahui bahwa nilai $\mathrm{t}$ hitung untuk dimensi personnel (X2) sebesar 4,629>1,960, ini berarti bahwa terdapat pengaruh yang signifikan antara dimensi personneldengan kepuasan.

3. Hasil uji t parsial dapat diketahui bahwa nilai $\mathrm{t}$ hitung untuk dimensi roles $(\mathrm{X} 3)$ sebesar 2,270>1,960, ini berarti bahwa terdapat pengaruh yang signifikan antara dimensi roles dengan kepuasan.

4. Hasil uji t parsial dapat diketahui bahwa nilai t hitung untuk dimensi scripts (X4) sebesar $-2,46<1,960$, ini berarti bahwa tidak terdapat pengaruh yang signifikan antara dimensi scripts dengan kepuasan.

Dari keempat sub variabel dari analisis service delivery tersebut, dapat disimpulkan bahwa sub variabel personnel mempunyai pengaruh yang besar. Karena taraf signifikansinya yaitu 0,000 nilai $\mathrm{B}$ dan nilai $\mathrm{t}_{\text {hitung }}$ lebih besar dari variabel lain. Hal tersebut bisa dilihat pada Tabel 4.27 diatas. Hal ini dikarenakan, menurut Fandy Tjiptono
(2011:176), jasa merupakan sesuatu yang sifatnya personal, artinya dilakukan oleh individu tertentu dan ditujukan kepada individu lainnya. Oleh sebab itu, setiap pelanggan harus dilayani secara personal sesuai dengan kebutuhan dan keinginannya masing-masing. Menurut Zeithaml (2009:60) pelaku pelayanan atau service actors merupakan penampil bagi setiap pelayanan yang dipersembahkan saat itu juga, pentingnya mereka naik dalam tiga kondisi. Pertama, service actors kritis ketika adanya kontak personal yang tinggi dengan pelanggan. Kondisi kedua adalah dimana keahlian service actors melibatkan kontak yang berulang. Kondisi ketiga adalah dimana contact personnel kritis saat mereka memiliki kebijaksanaan dalam menentukan jenis dalam jasa dan bagaimana menyampaikannya.

Selanjutnya, sub variabel service delivery yang memiliki pengaruh yang signifikan dengan kepuasan adalah roles. Zeithaml (2009:62) menyatakan bahwa kesuksesan dalam kinerja layanan tergantung pada bagian dari bagaimana peran atau role yang dilakukan dengan baik oleh service actors dan bagaimana tim dari pemain, yaitu karyawan dan pelanggan, berakting sesuai dengan perannya.

Selanjutnya, sub variabel service delivery yang tidak memiliki pengaruh yang signifikan terhadap kepuasan adalah service facilities dan scripts. Menurut Lovelock dan Wirtz (2011: 72), however, not all services involve tightly scripted performances. Scripts 
tend to be more flexible for providers of highly customized services-designers, educators, consultant and may vary by situation and by customer.

Selain itu, menurut pihak marketing Objek Wisata Linggarjati Indah Kabupaten Kuningan, sub variabel service facilities dan scripts bukanlah hal utama yang diperhatikan oleh wisatawan. Wisatawan berkunjung dan membeli paket outbound di Objek Wisata Linggarjati Indah Kabupaten Kuningan dikarenakan faktor harga yang sangat terjangkau serta lokasi yang mudah untuk dikunjungi dan jarak tempuh menuju lokasi yang tidak terlalu jauh sehingga dapat lebih menghemat biaya akomodasi.

\subsubsection{Model Persamaan Regresi} Berganda Pengaruh Service Delivery terhadap Kepuasaan Wisatawan yang Menggunakan Paket Outbound di Objek Wisata Linggarjati Indah Kabupaten Kuningan

Hasil analisa data dengan bantuan pengolahan komputer berdasarkan perhitungan SPSS 18 for windows diperoleh persamaan regresi berganda sebagai berikut:

$Y=a+b_{1} X_{1}+b_{2} X_{2}+b_{3} X_{3}+b_{4} X_{4}$

Berdasarkan hasil pengolahan data maka persamaan regresi berganda untuk service delivery adalah:

$Y=24,074+(-0,43)(\mathrm{X} 1)+0,479(\mathrm{X} 2)+0,225(\mathrm{X} 3)+(-0,12)$ (X4)

Dimana:

$\begin{array}{lll}\mathrm{Y} & = & \text { kepuasan wisatawan } \\ \mathrm{X} 1 & = & \text { service facilities } \\ \mathrm{X} 2 & = & \text { personnel } \\ \mathrm{X} 3 & = & \text { roles } \\ \mathrm{X} 4 & = & \text { scripts }\end{array}$

Pada dasarnya, nilai B constant adalah 24,074, hal tersebut menyatakan bahwa jika service facilities, personnel, roles dan scripts diabaikan, maka nilai kepuasan tamu adalah 24,074. Apabila service facilities dinaikan satu satuan, maka nilai kepuasan turun sebesar -0,43, dengan asumsi variabel independen lainnya bernilai tetap. Apabila personnel dinaikan satu satuan, maka nilai kepuasan akan naik sebesar 0,479 , jika roles dinaikan satu satuan, maka nilai kepuasan tamu akan naik sebesar 0,225. Serta jika scripts dinaikan satu satuan, maka nilai kepuasan turun sebesar -0,12 dengan asumsi variabel independen lainnya bernilai tetap. Sub variabel service delivery yang paling berpengaruh adalah roles.
V. KESIMPULAN

Berdasarkan hasil penelitian yang telah dilakukan dengan menggunakan analisa deskriptif dan verifikatif mengenai pengaruh service delivery terhadap kepuasan wisatawan yang menggunakan paket outbound di Objek Wisata Linggarjati Indah Kabupaten Kuningan dapat diambil kesimpulan sebagai berikut:

1. Secara umum tanggapan wisatawan yang menggunakan paket outbound di Objek Wisata Linggarjati Indah Kabupaten Kuningan mengenai service delivery yang terdiri dari service facilities, personnel, roles dan script memiliki respon yang baik. Pelaksanaan sub variabel dari service delivery sudah dilaksanakan dengan baik, terbukti dengan tanggapan wisatawan terhadap service delivery yang berada pada posisi tinggi pada garis kontinum. Sub variabel service facilities mendapatkan respon yang paling tinggi dari wisatawan. Hal ini dikarenakan fasilitas merupakan hal pertama yang diperhatikan oleh wisatawan saat berkunjung ke suatu objek wisata.

2. Tanggapan wisatawan terhadap kepuasan yang terdiri dari service delivery yang diterima dibandingkan dengan service delivery yang diharapkaan secara umum mendapatkan tanggapan yang baik dari pengunjung. Kontribusi paling tinggi dari kepuasan wisatawan adalah scripts. Hal ini dikarenakan dalam pelaksanaan outbound ada beberapa hal yang harus dimiliki oleh seorang instruktur outbound. Tidak hanya yang berkenaan dengan fisik, namun juga skill seperti kemampuan berbahasa, greeting, serta tanggung jawab dari instruktur outbound pada saat mendampingi wisatawan.

3. Berdasarkan pengujian hipotesis secara simultan menunjukan bahwa service delivery yang terdiri dari service facilities, personnel, roles dan scripts memiliki pengaruh yang signfikan terhadap kepuasan wisatawan. Sedangkan pengujian hipotesis secara parsial menunjukan bahwa sub variabel personneldan roles memiliki pengaruh yang signifikan terhadap kepuasan wisatawan. Namun sub variabel service facilities dan scripts tidak berpengaruh terhadap kepuasan wisatawan yang menggunakan paket outbound di Objek Wisata Linggarjati Indah Kabupaten Kuningan. Sub variabel yang memiliki 
pengaruh paling besar adalah personnel dibandingkan dengan roles.

\section{DAFTAR PUSTAKA}

Dinas Pariwisata dan Kebudayaan Kabupaten Kuningan. 2012. Data dan Informasi Pariwisata dan Kebudayaan Kabupaten Kuningan. Kuningan.

Duwi Priyanto. 2011. Buku Saku SPSS, Analisis Statistik Data. Jakarta: PT. Buku Seru.

Eva Ratna Sari. 2009. Pengembangan Wisata Kawasan Linggarjati Tahun 19962006: Skripsi Sarjana Fakultas Ilmu Budaya UNDIP, UNDIP Semarang: tidak diterbitkan.

Fandy Tjiptono. 2011. Pemasaran Jasa. Sleman: Bayu Media. dan Gregorius Chandra. 2008. Service, Quality \& Satisfaction. Yogyakarta: Andi Offset.

Farida Jasfar. 2009. Manajemen Jasa Pendekatan Terpadu. Ciawi Bogor: Ghalia Indonesia.

Hannie. 2008. Analisis Keamanan dan Kualitas Pelayanan Pada PT. Vayatour Dengan Metode Customer Satisfaction Index (CSI). Bekasi: tidak diterbitkan

Hendra Hermawan. 2010. Analisis Purchase and Service Encounter Cost di Grand Pasundan Convention Hotel Terhadap Kepuasan Tamu. Skripsi Sarjana Pariwisata FPIPS UPI. Bandung; tidak diterbitkan.

Hoyer and Macinnis. 2008. Consumer Behavior $5^{\text {th }}$ ed. South-Western, Cengage Learning.

Husein Umar. 2009. Metode Penelitian Untuk Skripsi dan Tesis Bisnis Edisi Kedua. Jakarta: Rajawali Pers.

Iqbal Hasan. 2009. Analisis Data Penelitian Statistik. Jakarta: Bumi Aksara.

Kaihatu, Thomas Stefanus. 2010. Analisa Kesenjangan Kualitas Pelayanan dan Kepuasan Konsumen Pengunjung Plaza Tunjungan Surabaya. Fakultas Ekonomi Universitas Kristen Petra, Surabaya.

Kotler and Amstrong. 2012. Principles of Marketing $14^{\text {th }}$ ed. Pearson Hall. New Jersey. and Keller. 2012. Marketing Management $14^{\text {th }}$ ed. Pearson Hall. New Jersey.

Kurtz, D. L, and Boone. 2011. Principles of Contemporary Marketing. International Edition.
Lovelock, Christopher and Lauran Wirtz. 2011. Service Marketing $7^{\text {th }}$ ed. Pearson Hall. New Jersey. and Lauren Wright. 2002. Principles of marketing and management, second edition. Phipe Prentice Hall.

Lucas, R. W. 2009. Customer Service Skills for Success $4^{\text {th }}$ ed. The McGraw-Hill. International Edition.

Morrison, A. M. 2010. Hospitality and Travel Marketing $4^{\text {th }}$ ed. Delmar Cengage Learning.

Peter, J. Paul and Olson, Jerry C. 2010. Consumer Behavior \& Marketing Strategy $9^{\text {th }}$ ed. The McGraw-Hill. International Edition.

Rangkuti, Freddy. 2006. Measuring Customer Satisfaction. Jakarta: PT. Sun

Ryan Kurniawan, SE., MM. Pengaruh Kinerja Penyampaian Jasa (Service Delivery) terhadap Nilai Pelanggan (Customer Value) serta Implikasinya Pada Loyalitas Pelanggan (Suatu Studi Pada Pelanggan Hotel Savoy Homann Bandung).

Riduwan, Dr. M.B.A. 2009. Pengantar Statistika Sosial. Bandung: Alfabeta

Schiffman, Leon. G and Lazer, Leslie. 2010. Consumer Behavior, $10^{\text {th }}$ ed. Pearson

Suwantoro, Gamal. 2004. Dasar-Dasar Pariwisata. Andi: Yogyakarta

Ulber Silalahi. 2009. Metode Penelitian Sosial. Bandung: PT. Refika Aditama

Solomon, Marshall, Stauart. 2009. Marketing $6^{\text {th }}$ ed, (Real People, Real Choices). Pearson. International Edition.

Sugiyono. 2010. Metode Penelitian Bisnis. Bandung: Alfabeta 2011. Statistika Untuk Penelitian.Bandung: Alfabeta

Suharsimi Arikunto. 2010. Prosedur Penelitian: Suatu Pendekatan Praktek (edisi revisi 2010). Jakarta: PT. Rineka Cipta

Swink, Melnyk, Cooper, and Hartley. 2011. Managing Operations Across The Chain. The McGraw-Hill. International Edition.

Uma Sekaran. 2008. Metodologi Penelitian untuk Bisnis, Edisi 4. Yogyakarta: Salemba.

Undang-Undang Kepariwisataan No. 10 (2009).

Walker, Orville C dan John W. Mullins. 2011. Marketing Strategy A Decision 
Focused Approach $7^{\text {th }}$ ed. The McGraw-Hill. International Edition.

Yoeti, Oka A. 2008. Tours and Travel Management. PT. Pradnya Paramita: Jakarta

Zeithaml, V.A., M.J. Bitner. 2009. Service Marketing: Integrating Customer Focus Across the Firm $5^{\text {th }} e d$. McGraw-Hill. Boston.

\section{Internet:}

analisis.vivanews.com kerockan.blogspot.com rahmat-adventure.blogspot.com www.bps.com www.kabarbisnis.com www.kimpraswil.go.id www.linggarjati-indah.co.id www.tempointeraktif.com www.westjava-indonesia.com 
